Chemical Technology Division

\title{
CONCENTRATION OF MELTON VALLEY STORAGE TANK SURROGATES WITH A WIPED FILM EVAPORATOR
}
M. D. Boring
L. L. Farr
V. L. Fowler
J. D. Hewitt

Date Published - August 1994

Prepared for the

OAK RIDGE NATIONAL LABORATORY

Oak Ridge, Tennessee 37831-6330 managed by

MARTIN MARIETTA ENERGY SYSTEMS, INC.

for the

U.S. DEPARTMENT OF ENERGY

under contract DE-AC05-84OR21400 


\section{DISCLAIMER}

This report was prepared as an account of work sponsored by an agency of the United States Government. Neither the United States Government nor any agency thereof, nor any of their employees, make any warranty, express or implied, or assumes any legal liability or responsibility for the accuracy, completeness, or usefulness of any information, apparatus, product, or process disclosed, or represents that its use would not infringe privately owned rights. Reference herein to any specific commercial product, process, or service by trade name, trademark, manufacturer, or otherwise does not necessarily constitute or imply its endorsement, recommendation, or favoring by the United States Government or any agency thereof. The views and opinions of authors expressed herein do not necessarily state or reflect those of the United States Government or any agency thereof. 


\section{DISCLAIMER}

\section{Portions of this document may be illegible in electronic image products. Images are produced from the best available original document.}




\section{CONTENTS}

Page

LIST OF FIGURES $\ldots \ldots \ldots \ldots \ldots \ldots \ldots \ldots \ldots \ldots \ldots \ldots \ldots \ldots \ldots \ldots \ldots \ldots \ldots$ iv

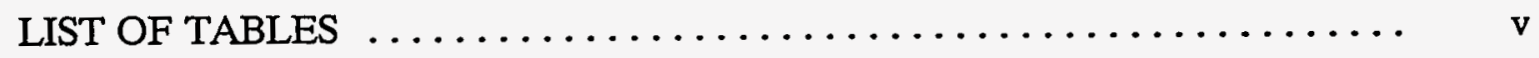

ABSTRACT $\ldots \ldots \ldots \ldots \ldots \ldots \ldots \ldots \ldots \ldots \ldots \ldots \ldots \ldots \ldots \ldots \ldots \ldots \ldots \ldots$

1. INTRODUCTION $\ldots \ldots \ldots \ldots \ldots \ldots \ldots \ldots \ldots \ldots \ldots \ldots \ldots \ldots \ldots \ldots \ldots$

2. BACKGROUND $\ldots \ldots \ldots \ldots \ldots \ldots \ldots \ldots \ldots \ldots \ldots \ldots \ldots \ldots \ldots \ldots \ldots \ldots$

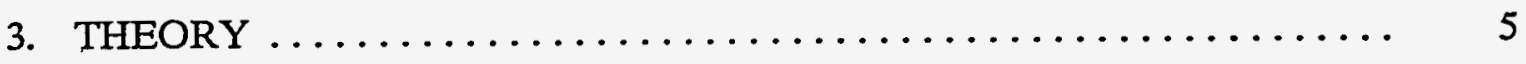

4. EXPERIMENTAL PARAMETERS $\ldots \ldots \ldots \ldots \ldots \ldots \ldots \ldots \ldots \ldots \ldots \ldots, 8$

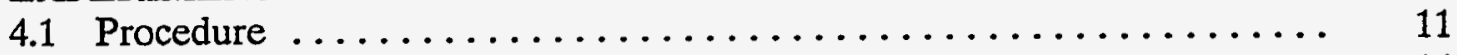

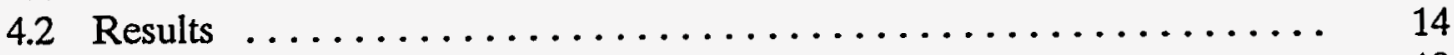

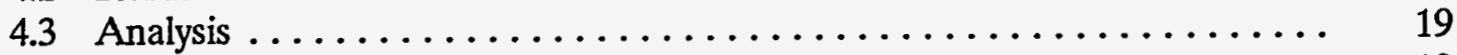

4.3.1 Effect of Feed Rate and Feed Temperature ............. 19

4.3.2 Effect of Rotor Speed ........................ 25

4.3.3 Decontamination Factors ....................... 27

4.3.4 Heating Efficiency $\ldots \ldots \ldots \ldots \ldots \ldots \ldots \ldots \ldots \ldots \ldots, 28$

4.3.5 Postinspection of WFE Components ............... 31

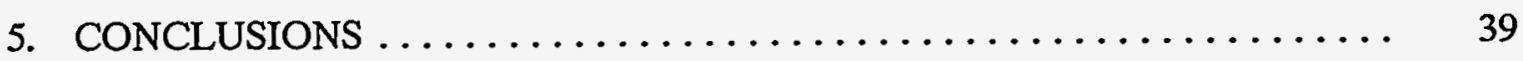

6. VARIABLE DICTIONARY $\ldots \ldots \ldots \ldots \ldots \ldots \ldots \ldots \ldots \ldots \ldots \ldots \ldots \ldots \ldots$

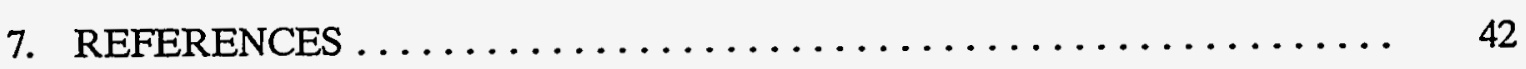




\section{FIGURES}

Page

1. Schematic diagram of WFE experiment $\ldots \ldots \ldots \ldots \ldots \ldots \ldots \ldots \ldots \ldots$

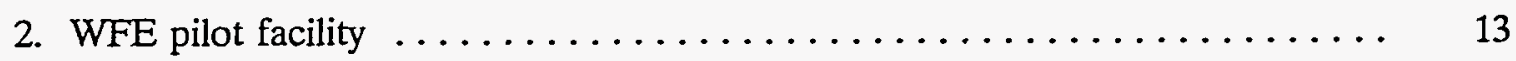

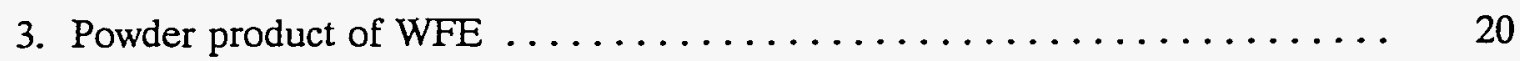

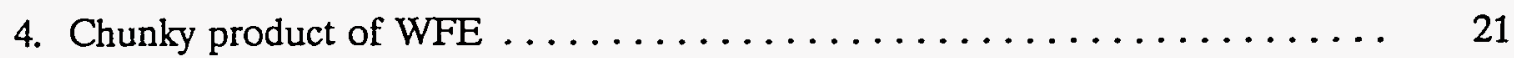

5. Volume reduction vs flow rate $\ldots \ldots \ldots \ldots \ldots \ldots \ldots \ldots \ldots \ldots \ldots \ldots \ldots \ldots \ldots$

6. Volume reduction vs feed temperature $\ldots \ldots \ldots \ldots \ldots \ldots \ldots \ldots \ldots \ldots$

7. Volume reduction vs rotor speed $\ldots \ldots \ldots \ldots \ldots \ldots \ldots \ldots \ldots \ldots \ldots$

8. Corroded rotor from progressive cavity feed pump $\ldots \ldots \ldots \ldots \ldots \ldots \ldots$

9. Evaporator heat transfer surface after supernate trials $\ldots \ldots \ldots \ldots \ldots \ldots$

10. Corrosion damage to blade 6 of WFE $\ldots \ldots \ldots \ldots \ldots \ldots \ldots \ldots \ldots \ldots \ldots \ldots$

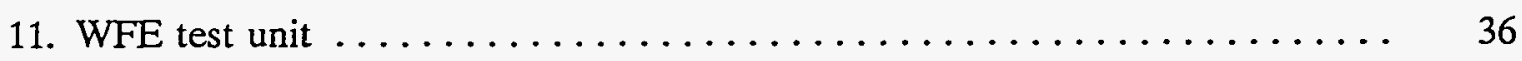




\section{TABLES}

Page

1. Composition of MVST unit W-24 liquid waste $\ldots \ldots \ldots \ldots \ldots \ldots \ldots$

2. Composition of MVST $W-24$ sludge $\ldots \ldots \ldots \ldots \ldots \ldots \ldots \ldots \ldots \ldots$

3. Composition of surrogate supernate $\ldots \ldots \ldots \ldots \ldots \ldots \ldots \ldots \ldots \ldots \ldots$

4. Composition of $\mathrm{W}-24$ surrogate sludge $\ldots \ldots \ldots \ldots \ldots \ldots \ldots \ldots \ldots$

5. Experimental matrix for supernate studies $\ldots \ldots \ldots \ldots \ldots \ldots \ldots \ldots$

6. Results of supernate studies $\ldots \ldots \ldots \ldots \ldots \ldots \ldots \ldots \ldots \ldots \ldots \ldots \ldots$

7. Estimated radiological contents of MVST condensate ............. 29 


\title{
CONCENTRATION OF MELTON VALLEY STORAGE TANK SURROGATES WITH A WIPED FILM EVAPORATOR
}

\author{
M. D. Boring \\ L. L Farr \\ V. L. Fowler \\ J. D. Hewitt
}

\begin{abstract}
This report describes experiments to determine whether a wiped film evaporator (WFE) might be used to concentrate low-level liquid radioactive waste (LLLW). Solutions used in these studies were surrogates that contained no radionuclides. The compositions of the surrogates were based on one of Oak Ridge National Laboratory's (ORNL's) Melton Valley Storage Tanks (MVSTs). It was found that a WFE could be used to concentrate LLLW to varying degrees by manipulating various parameters. The parameters studied were rotor speed, process fluid feed temperature and feed rate, and evaporator temperature. Product consistency varied from an unsaturated liquid to a dry powder. Volume reductions up to $68 \%$ were achieved. System decontamination factors were consistently in the range of $10^{4}$.
\end{abstract}

\section{INTRODUCTION}

Oak Ridge National Laboratory (ORNL) has an ongoing need to process and dispose of waste consisting largely of thick calcium carbonate, aluminum hydroxide, and magnesium hydroxide sludges, suspended in about $4 \underline{\mathrm{M}}$ solutions of sodium nitrate. Smaller quantities of other salts are also present in the liquid. Transuranic radionuclides (TRU) are present in varying concentrations in the sludges. Significant quantities of the betagamma emitters, ${ }^{137} \mathrm{Cs}$ and ${ }^{90} \mathrm{Sr}$, are present in the liquids and the. sludges. The liquids and sludges are considered mixed waste because of the presence of radionuclides and nonradioactive heavy metals regulated under the Resource Conservation and Recovery Act (RCRA). Large volumes of these materials are stored in the Melton Valley Storage Tanks (MVSTs) and in several other storage tanks at ORNL. 
The MVST facility was commissioned in the mid-1970s. Its main purpose at the time of startup was to act as a holding facility for the hydrofracture process. The hydrofracture process was an operation used to dispose of liquid radioactive waste. This operation consisted of mixing the waste with grout and injecting the mixture into an underground shale formation.

The hydrofracture process was suspended in 1984 in response to Chapter 1200-46 ("Underground Injection Control Regulations") of "The Rules of the Water Quality Board for the State of Tennessee." Since that time, the MVSTs have been used to store radioactive wastes from past and present ORNL operations. A significant fraction of the waste is from past nuclear fuel reprocessing pilot plants. Other sources of waste include radioisotope production activities, reactor operations, laboratories, and waste treatment operations.

As of December 1, 1993, an estimated 455,000 gal of liquid low-level waste (LLLW) were awaiting disposal. ${ }^{1}$ The bulk of this waste is contained in 12 tanks. Eight of the tanks are the MVST W-24 through W-31, located in Melton Valley. The other four tanks, located in Bethel Valley, are the evaporator service tanks C-1, C-2, W-21, and W-23. These tanks are rapidly approaching their collective Operational Safety Requirement (OSR) limit of 520,000 gal. Current strategy calls for short-, medium-, and long-term plans for management of MVST wastes and for radioactive wastes being generated now and in the future. The near-term plan consisted of efforts to (1) minimize waste, (2) remove excess in-tank water by evaporation, and (3) solidify MVST waste in a concrete matrix as necessary to create additional storage space. The intermediate plan calls for processing MVST sludge for subsequent disposal at the Waste Isolation Pilot Plant (WIPP) in Carlsbad, New Mexico. The long-term plan calls for construction of an on-site low-level waste disposal facility for non-TRU waste and for minimization of TRU generated waste. ${ }^{2}$

If the intermediate plans are to be carried out, a facility to prepare MVST waste for WIPP must be developed. This facility will include a method to remove the waste from the MVST, solidify it, and package it for shipment to WIPP. This report presents the results of experiments to determine whether a specially designed wiped film evaporator (WFE) might be used in the solidification step. The special feature of this unit is the elimination of the bottom bearing. This modification allows for the free flow of 
solid product out the bottom of the unit, eliminates the possibility of bottom bearing failure, and would allow the unit to be removed remotely from a hot cell operation. ${ }^{3}$

\section{BACKGROUND}

To prepare these wastes for shipment to the WIPP, the concept of the Waste Handling and Packaging Plant (WHPP) was developed. The primary functions of the WHPP will be to (1) prepare solid wastes currently stored in concrete casks around ORNL for shipment to WIPP and (2) to retrieve the material from the MVST and process the waste into a form that meets the waste acceptance criteria (WAC) for WIPP. Notable parameters in the WIPP WAC with regard to the MVST contents are that the resulting waste packages contain no free liquid and no respirable fines ( $\leq 1 \%$ particulates below $10 \mu \mathrm{m}$ and $\leq 15 \%$ particulates below $100 \mu \mathrm{m}$ ). Processing the MVST waste through WHPP is the current baseline technology for meeting the Department of Energy (DOE) requirements for TRU liquid waste disposal at the WIPP. ${ }^{2}$

One method of concentrating and solidifying these salt supernates and sludges is through evaporative techniques. The Preliminary Conceptual Design Report (PCDR) ${ }^{4}$ for WHPP envisioned the use of a kettle-type evaporator followed by extrusion as a melted salt. One characteristic of salt solutions and sludges is that the more concentrated in suspended solids the material is, the higher the viscosity of the liquid. Fundamental engineering relationships show that the amount of heat transfer diminishes with increasing viscosity. The sludges that will be retrieved from the MVST have been characterized as a Bingham Plastic. That is, the viscosity is inversely proportional to the rate of shear once a minimum rate of shear called the plastic viscosity has been achieved. Literature sources indicate that the increased shearing effect created by the use of a WFE could be used to lessen these viscosity effects to a significant degree. Furthermore, the agitation caused by the blades and the thin film thus produced keep the heat transfer in a highly turbulent boundary layer flow regime. 5 Since the MVST wastes are to be solidified, the WFE appeared to be a candidate for the evaporative unit operation in WHPP. WFEs have already been used to concentrate radioactive waste at other sites; the most notable of these is the Savannah River Plant. ${ }^{6}$ 
In FY 1989 and 1990, vendor tests were conducted off-site by ORNL Chemical Technology Division staff. Surrogate materials that simulated the properties of the MVST supernates and sludges were used. The results of these tests indicated that a WFE could be used to produce concentrated slurries, dry powders, and/or fused salts. ${ }^{7}$ It was found that a sludge consisting of $\sim 30 \%$ solids could be volume reduced by $62.5 \%$. The product was a slurry that was $81 \%$ solids. Overall heat transfer coefficients ranging from 600 to $797 \mathrm{Btu} /\left(\mathrm{h}-\mathrm{ft}^{2}-{ }^{\circ} \mathrm{F}\right)$ were achieved on the vendor's 4-in.-ID 1.7- $\mathrm{ft}^{2}$ unit. ${ }^{8}$ Vendor information states that this value would be closer to $200-300 \mathrm{Btu} /\left(\mathrm{h}-\mathrm{ft}^{2}-{ }^{\circ} \mathrm{F}\right)$ for a larger, 10-in.-diam unit. ${ }^{9}$ A value of $5.3 \mathrm{gal} / \mathrm{h}$ evaporated per square foot heat transfer was calculated for the 10-in.-diam unit.

As a result of these vendor studies a WFE was included in the conceptual plans for the WHPP pilot facility. This WHPP Development Facility (WDF) was built to model the various unit operations of WHPP. These processes include slurry mixing, mobilization, transport, and solidification. The WDF included a steam-heated pilot- scale WFE unit, specially designed for remote operation, to be coupled with a microwave unit, which would solidify the concentrated product of the WFE. The design of the evaporator called for a flow rate of $0.5 \mathrm{gal} / \mathrm{min}$. Calculations based on the data from the vendor studies indicated that a unit with a $4.9-\mathrm{ft}^{2}$ heat transfer area would be sufficient to fully evaporate 0.5 gal/min water. Construction of the WDF was completed in early FY 1993.

The evaporator facility consists of a 500-gal mixing tank; an insulated 500-gal preheat/feed tank; the WFE, which possesses a $5.4-\mathrm{ft}^{2}$ heat transfer surface area; a product collection station; a heat exchanger to condense the evaporated distillate; a 250 -gal distillate receiver tank; a cooling water dechlorination unit; assorted piping and fluid transport media; and a remote data acquisition and control station. The heating jacket of the evaporator is heated with 150 -psig saturated steam to $180^{\circ} \mathrm{C}\left(368^{\circ} \mathrm{F}\right)$. The mixing tank can be heated with 50 -psig steam to $147^{\circ} \mathrm{C}\left(298^{\circ} \mathrm{F}\right)$. The evaporator is also flexible enough to accommodate a hot oil system, which would allow the unit to be heated to $\sim 350^{\circ} \mathrm{C}$.

It is anticipated that operation of this facility will give information about the following items: 
1. Capability to process MVST wastes to a thick slurry suitable for feeding to a microwave unit or to produce a solid form suitable for storage in WIPP without the microwave unit.

2. Ranges of appropriate operating conditions for processing the MVST waste.

3. Reliability of the equipment for remote operation.

4. Potential corrosion problems.

5. Physical and chemical characteristics of the product and distillate.

6. Effects of the waste on the evaporator heat exchange surface due to erosion/corrosion and scaling.

7. Decontamination factors and the necessity for further treatment of the distillate and off-gas.

\section{THEORY}

The most difficult parameter to determine in most heat transfer calculations where steam is used as the heating fluid is the process side film heat transfer coefficient $\left(h_{i}\right)$. This value is one of the three resistances that make up the overall heat transfer coefficient $\left(U_{o}\right)$.

$$
\frac{1}{U_{o}}=\frac{1}{h_{i}}+\frac{L}{k}+\frac{1}{h_{o}}
$$

The value of the thermal conductivity $(k)$ is easily measured and is well documented in the literature for many materials. Values are readily available for nearly all heat transfer mediums. The value of the heating fluid side film coefficient is also well correlated when steam is used as the heating fluid and film condensation is to be expected. Nusselt's equation (shown below) expresses the relationship for $h_{o}$ assuming film condensation of steam and the absence of noncondensing gases. ${ }^{10}$ Even when the heat transfer surface is highly polished, it appears that film condensation predominates. It is difficult to maintain dropwise condensation on any surface for an extended period of time without promoters. ${ }^{11}$ While ORNL steam should be free of noncondensing gases, float thermostatic steam traps were installed to diminish the effect of any noncondensing gases there may be. 


$$
h_{0}=0.943\left(\frac{k_{l}^{3} \rho^{2} g h_{f g}}{L \mu \Delta T}\right)^{1 / 4} .
$$

Very little information is available on the inside film coefficient for agitated thin-film equipment. Dieter ${ }^{12}$ presents a nomogram and the following equation for calculating $h_{i}$. This equation was developed for a Newtonian fluid; however, it gave good agreement with $h_{i}$ data from a WFE used to concentrate nuclear wastes characterized as Bingham Plastics at the Savannah River Plant. ${ }^{13}$

$$
h_{i}=963\left(\frac{N}{\mu}\right)^{1 / 3} k_{l} .
$$

Skelland et al. ${ }^{14}$ have also reported a correlation for $h_{i}$ in scraped surface equipment. If this relationship could be adapted for WFEs, it would be particularly useful since equations for equipment scaleup are also presented. ${ }^{14}$

These correlations were used in this study to determine theoretical values for $U_{o}$. These values were then compared with those calculated using experimental data. Values of $U_{o}$ were calculated from the following relationship. In this equation subscript 1 refers to the condensing steam, subscript 2 refers to the amount of process liquid being evaporated, subscript 3 refers to the amount of process material being solidified, and subscript 4 refers to the mass flow rate of the feed.

$$
\begin{aligned}
& Q=m_{1}\left(h_{f g}\right)=U_{\delta} A \Delta T_{L M} t \\
& =m_{2} h_{f g}+m_{3} h_{f c}+\dot{m}_{4} C_{p} \Delta T
\end{aligned}
$$

The amount of heat supplied to the system was determined by taking a timed volume of steam condensate once the system had reached steady state. It was then assumed that this value was representative of the steam flow for the entire trial. The value of the boiling point was determined by extrapolating data that were available on $\mathrm{W}$ 24 MVST wastes. ${ }^{15}$ Heat capacities were determined by multiplying mole fractions of the 
materials in the surrogates by their respective heat capacities and adding the results. Average values were assumed based on inlet and outlet conditions. The latent heat of vaporization of the process fluid was assumed to be that of pure water. All other values could be calculated directly from instrument readings, could be analyzed for with standard laboratory procedures, or were well documented in the literature. ${ }^{16,17,18}$ These values also allowed for the calculation of the efficiency of heat transferred.

The log mean temperature difference was calculated as follows:

$$
\left(\frac{\Delta T_{\text {inlet }}-\Delta T_{\text {outlet }}}{\ln \frac{\Delta T_{\text {inlet }}}{\Delta T_{\text {outlet }}}}\right) \text {. }
$$

The efficiency of steam utilization was defined as follows. In this equation $m_{1}$ refers to the mass of process liquid evaporated, $\underline{\underline{m}}_{2}$ refers to the mass flow rate of the material being concentrated, and $m_{3}$ refers to the mass of the steam condensed.

$$
E=\left(\frac{m_{1} h_{f g}+\dot{m}_{2} C_{p} \Delta T t}{m_{3} h_{f g}}\right) \times 100
$$

It was also hoped that these studies would give an indication as to how much volume reduction could be accomplished at various conditions. The importance of determining whether any contaminants would be entrained in the condensate has already been stated. Therefore, decontamination factors (DFs) and volume reduction $\left(V_{r}\right)$ calculations were also done with the data from these experiments. The following equations were used to calculate $V_{r}$ along with system and evaporator DFs. System DFs are defined as the concentration of a particular species in the feed divided by the concentration of that species in the distillate. Evaporator DFs are defined as the concentration of a particular species in the product divided by the concentration of that species in the distillate. In these equations, subscript " $a$ " is indicative of species " $a$ ". Parameters for calculating $V_{r}$ were determined as follows. The depth of material collected in the product receiver was measured with a yardstick and converted to volume. This volume was then divided by the volume of material processed. Material balances vs amount of feed of between 90 and 95\% were consistently achieved by collection of all products. 


$$
\begin{gathered}
V_{r}=\left(\frac{V_{i}-V_{p}}{V_{i}}\right) \times 100, \\
D F_{\text {sys }}=\left(\frac{C_{a i}}{C_{a d}}\right), \\
D F_{\text {exap }}=\left(\frac{C_{a p}}{C_{a d}}\right) .
\end{gathered}
$$

\section{EXPERIMENTAL PARAMETERS}

The compositions of the surrogate supernate and sludges used in these evaporation studies were based on analyses done on the W-24 MVST. The concentrations shown in Tables 1 and 2 are laboratory analyses performed in the late 1980s during a campaign to fully characterize the material contained in the MVSTs. ${ }^{20}$ The concentration of the radionuclides present in this tank are not reported in Tables 1 and 2 since they were not considered as makeup for the surrogate feed to the WFE. Tank W-24 was chosen as the basis for these studies because it represented the worst-case MVST waste from a heat transfer point of view. The material in this tank has a high silica concentration (245 $\mathrm{mg} / \mathrm{L}$ ). Silica is known to cause significant scaling in heat exchangers-(particularly in the presence of magnesium) when the solution $\mathrm{pH}$ is high. ${ }^{21}$ High $\mathrm{pH}$ solutions tend to promote foaming in heat exchangers - particularly at $\mathrm{pHs}$ above $9 .{ }^{22}$ Foaming could promote carryover of contaminants in the distillate. $\mathrm{W}-24$ has a $\mathrm{pH}$ of 13.1 .

Table 3 shows the composition of the supernate solution used in these studies. The concentrations shown in this table were calculated to duplicate the cation concentrations shown in Table 1. No effort was made to balance the anion concentrations with the exception of the chloride ion. The $0.26 \mathrm{~g} / \mathrm{L}$ of this ion was added as the sodium salt. A pH titration was then performed on the solution, and adjustments were made to raise or lower the $\mathrm{pH}$ to the desired value. Table 2 shows the ratio of weight percentages 
of the undissolved solids in the sludge samples taken from W-24. Large quantities of sodium and potassium were also found in the sludge, but these were believed to be present as part of the supernate. Table 4 shows the ratio of weight percentages of undissolved solids added to the supernate to make up the surrogate sludges for these studies. Once again, these percentages were calculated based on the cation composition of the sludges. Sludge mixtures at concentrations up to $40 \%$ undissolved solids will be studied in a later phase of this work.

Trial values of the operating parameters to be used in the supernate studies were obtained from preliminary experiments using only water as the process fluid. The results of the supernate studies will be used in setting the experimental matrix for the sludge studies.

Table 1. Composition of MVST unit W-24 liquid waste

\begin{tabular}{cc}
\hline Cation & $\begin{array}{c}\text { Concentration } \\
(\mathrm{g} / \mathrm{L})\end{array}$ \\
\hline $\mathrm{Na}^{+}$ & 100.0 \\
$\mathrm{~K}^{+}$ & 11.0 \\
$\mathrm{Si}^{4+}$ & 0.245 \\
$\mathrm{Ca}^{2+}$ & 7.200 \\
$\mathrm{Mg}^{2+}$ & $<1.3$ \\
\hline
\end{tabular}

Table 2. Composition of MVST W-24 sludge

\begin{tabular}{cc}
\hline Cation & $\begin{array}{c}\text { Concentration } \\
\text { (wt \% suspended solids) }\end{array}$ \\
\hline $\mathrm{Al}$ & 4.34 \\
$\mathrm{Ca}$ & 78.9 \\
$\mathrm{Mg}$ & 15.2 \\
$\mathrm{Fe}$ & 0.2 \\
\hline
\end{tabular}


Table 3. Composition of surrogate supernate

\begin{tabular}{|c|c|}
\hline Component & Concentration $(\mathrm{g} / \mathrm{L})$ \\
\hline $\mathrm{NaNO}_{3}$ & 369.80 \\
\hline $\mathrm{KNO}_{3}$ & 28.30 \\
\hline $\mathrm{Na}_{2} \mathrm{CO}_{3}$ & 15.90 \\
\hline $\mathrm{NaCl}$ & 4.27 \\
\hline $\mathrm{Ca}\left(\mathrm{NO}_{3}\right) \cdot 4 \mathrm{H}_{2} \mathrm{O}$ & 0.05 \\
\hline $\mathrm{MgCl}_{2} \cdot 6 \mathrm{H}_{2} \mathrm{O}$ & 0.01 \\
\hline $\mathrm{Na}_{2} \mathrm{SiO}_{3} \cdot 9 \mathrm{H}_{2} \mathrm{O}$ & 2.48 \\
\hline $\mathrm{NaOH}$ & 0.66 \\
\hline
\end{tabular}

Table 4: Composition of $\mathrm{W}-24$ surrogate sludge

\begin{tabular}{cc}
\hline Component & \multicolumn{2}{c}{$\begin{array}{c}\text { Concentration } \\
\text { (wt \% }\end{array}$} & suspended solids) \\
\hline $\mathrm{Al}(\mathrm{OH})_{3}$ & 6.5 \\
$\mathrm{CaCO})_{3}$ & 74.6 \\
$\mathrm{Mg}(\mathrm{OH})_{2}$ & 18.9 \\
\hline
\end{tabular}

Experiments were conducted in three phases. Phase I consisted of obtaining baseline data using water. These studies were conducted as a screening exercise to help set parameters for the supernate and sludge trials. Phase II of the experiments were the supernate studies. In addition to the laboratory data acquired through these trials, corrosion/erosion information was also obtained. Once the supernate studies had been completed, the evaporator shell and blades were removed, and dimensional and corrosion/erosion inspections of the equipment were performed. These results were compared to dimensional data collected prior to startup of the facility. Phase III of these experiments will consist of similar trials using sludges. Upon completion of these experiments, dimensional and corrosion/erosion inspections will also be performed to determine if any damage to the WFE occurred. This report discusses the first two phases of these studies. 
Prior to Phase I, four operating parameters were believed to be of importance: rotor speed, process fluid flow rate, evaporator setpoint temperature, and process fluid feed temperature. Temperature of the feed was controlled using a heat-traced feed line from the preheat tank and the steam jacket on the preheat tank. Heat conducted from the evaporator steam jacket through the feed line also had a noticeable effect on feed temperature. The following ranges of variables were investigated during the screening studies:

1. Rotor speed (250, 500, and $750 \mathrm{rpm})$.

2. Preheat tank temperature (ambient and $125^{\circ} \mathrm{F}$ ).

3. Evaporator temperature $\left(300\right.$ and $\left.350^{\circ} \mathrm{F}\right)$.

4. Process fluid feed rate $(0.1,0.25,0.5,0.75,1.0$, and $1.2 \mathrm{gal} / \mathrm{min})$.

Figure 1 is a schematic diagram of the WFE pilot facility, and Fig. 2 is a photograph of the facility. The following experimental procedure was followed for all tests with simulated supernate and sludges.

\subsection{PROCEDURE}

Proper quantities of each chemical to be used were weighed and set aside. The 500-gal bulk mixing tank was filled approximately half full of water. The pump recycle line for this tank was used to assist in the mixing of the liquid and chemicals. The agitator in the bulk mixing tank was turned on and set to a low speed. The chemicals were added to the tank as the agitator was turning. Once the chemicals had been added, additional water was added to the tank until a volume of $500 \mathrm{gal}$ was reached. The agitator speed was then increased, and the solution was mixed vigorously for several hours. A sample of this solution was taken and analyzed for various cations, nitrate ion concentrations, density, and $\mathrm{pH}$. A pH reading was also taken prior to beginning the experiments, and adjustments were made as necessary.

Once the chemicals were thoroughly mixed, the solution was pumped into the preheat/feed tank. The small recycle loop was then energized along with the mixer. This recirculation and agitation were used to encourage efficient heating to the desired feed temperature. Fifty-psig steam at $147^{\circ} \mathrm{F}\left(298^{\circ} \mathrm{F}\right)$ was used to heat the material. 


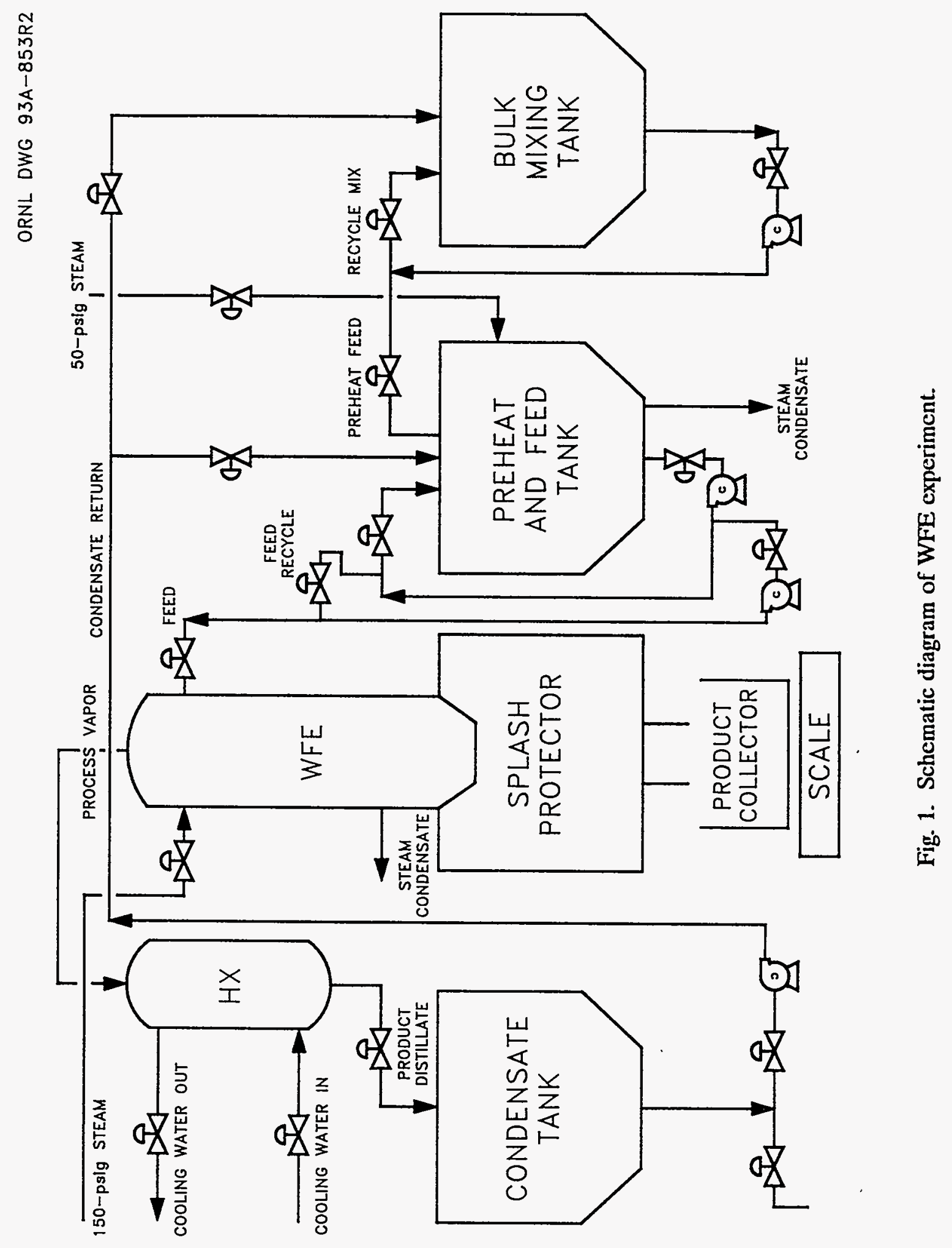




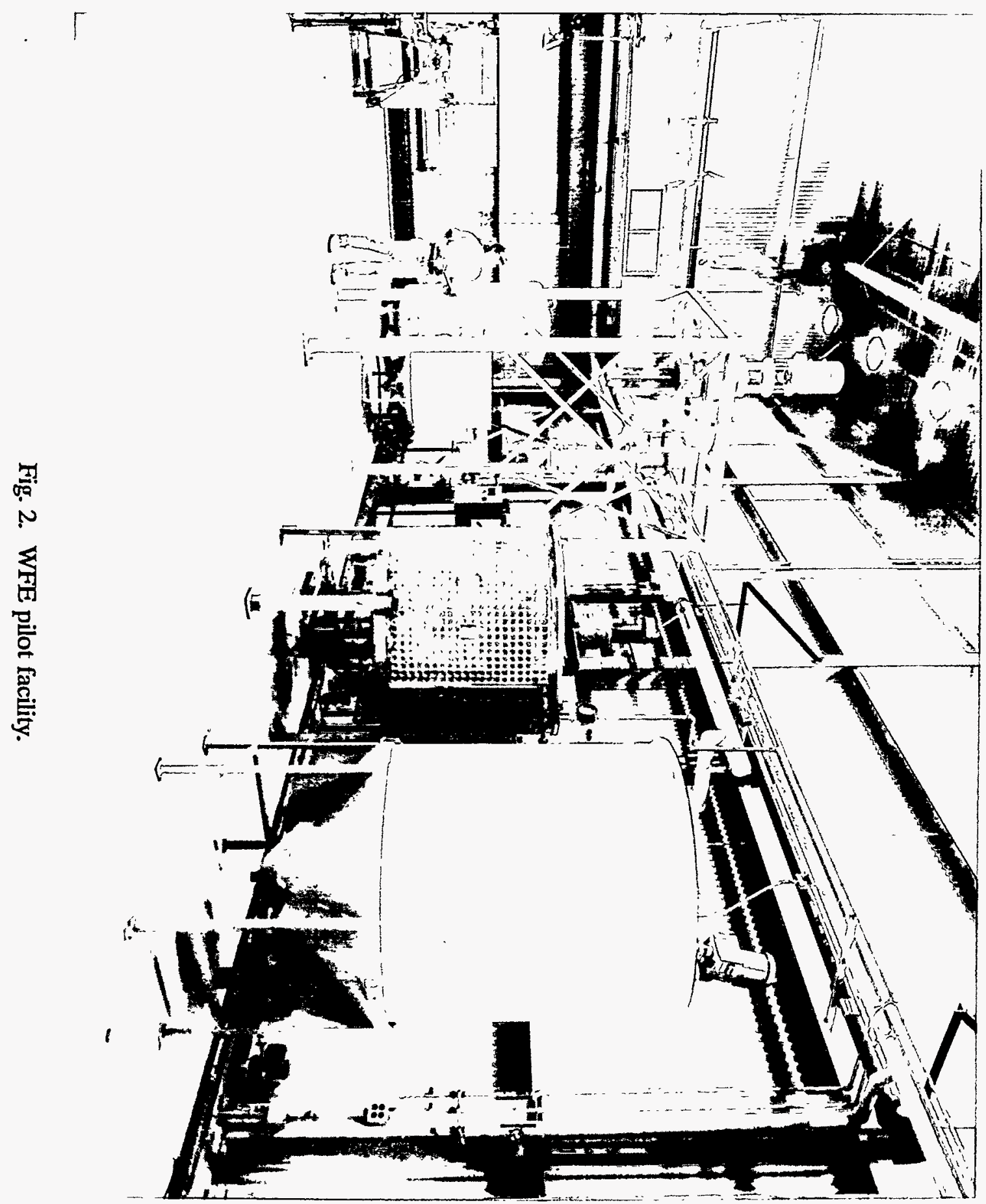


When the desired operating temperature had been reached, the feed recycle loop was energized, and the flow was allowed to stabilize at the desired rate. The evaporator temperature and rotor speeds were also set at this time. Once all variables were adjusted to the proper values, flow through the evaporator was initiated. Samples were taken via a grab sample port in the product collector once the system reached steady state. A sample of the distillate was also collected during each trial. These samples were then sent off for analysis. Like the feed solutions, these samples were analyzed for cation composition, nitrate ion concentration, density, and $\mathrm{pH}$.

During the water-only trials, data were taken only for baseline purposes. Therefore, each individual experiment was considered complete when data had been taken at steady state conditions for 10 gal of feed. Sludge and supernate runs were made until $40 \mathrm{gal}$ of feed had been processed. A 40-gal batch size was chosen to ensure that the 55 gal product collector could be easily managed during recycle operations. At the end of each experiment, the product was returned to the bulk mixing tank to be used as makeup for subsequent batches.

\subsection{RESULTS}

Results of the screening experiments with process water indicated that the highest feed tank and evaporator temperatures and lowest feed rate would give the best volume reduction $\left(V_{r}\right)$. Evaporator rotor speed also had a marked effect on volume reduction. A greater volume reduction was achieved at higher rotor speeds. In relation to rotor speed, the most noticeable improvement in evaporator performance was achieved when the rotor speed was increased from 250 to $500 \mathrm{rpm}$. A marginally better $V_{r}$ was observed for all conditions as the rotor speed was increased from 500 to $750 \mathrm{rpm}$. This improvement was most likely due to the increased turbulence in the boundary layer. A volume reduction of $72.9 \%$ was achieved for a flow rate of $0.1 \mathrm{gpm}$, an evaporator setpoint temperature of $350^{\circ} \mathrm{F}$, an evaporator feed tank temperature of $125^{\circ} \mathrm{F}$, and a rotor speed of $500 \mathrm{rpm}$. This was the best $V_{r}$ achieved. The worst volume reduction obtained was $17.8 \%$. This value occurred at a flow rate of $1.2 \mathrm{gal} / \mathrm{min}$, an ambient feed tank temperature, an evaporator setpoint temperature of $300^{\circ} \mathrm{F}$, and a rotor speed of $250 \mathrm{rpm}$. 
On the basis of the results of the screening trials, an experimental matrix was designed for the supernate studies. From the screening experiments, it was apparent that no appreciable evaporation could be obtained for an evaporator setpoint temperature of $300^{\circ} \mathrm{F}$. Therefore, all supernate experiments were performed at a setpoint temperature of $350^{\circ} \mathrm{F}$. Analyses of the screening experiments also revealed that no appreciable volume reductions could be achieved above a flow rate of $0.5 \mathrm{gal} / \mathrm{min}$. This value was used as a high limit for the supernate matrix.

The water trials indicated that $V_{r}$ was only a very weak function of rotor speed above $500 \mathrm{rpm}$. Since $500 \mathrm{rpm}$ produced much greater volume reductions than $250 \mathrm{rpm}$, it was decided to only do extensive experimentation at $500 \mathrm{rpm}$. The first nine experiments were performed at a rotor speed of $500 \mathrm{rpm}$. All combinations of the other variables (flow rate-0.1, 0.3, and $0.5 \mathrm{gal} / \mathrm{min}$, and feed tank temperature - ambient, 125, and $175^{\circ} \mathrm{F}$ ) were evaluated. The additional higher feed tank temperature was added to the matrix because the screening experiments indicated that this variable might have a strong influence on the results.

After the results of the first nine experiments were analyzed, two additional trials were planned. The conditions of these two experiments would be determined by the results of the first nine. These two tests would be performed at rotor speeds of 250 and $750 \mathrm{rpm}$. The other parameters (flow rate and feed tank temperature) would be defined by those values that had given the best volume reduction in the first nine trials. These trials were performed because it was believed that rotor speed would become a more significant parameter once the studies on the Bingham Plastic-like sludge were initiated, and some baseline data at different rotor speeds were needed.

Results of the first few experiments were not very promising. At higher feed rates and lower feed temperatures, only concentrated liquids could be produced. Therefore, an experiment was performed at $750 \mathrm{rpm}$ to verify that increasing the rotor speed above 500 rpm would not be a significant factor in supernate concentration. The other conditions for this experiment were flow rate, $0.3 \mathrm{gal} / \mathrm{min}$, and feed tank temperature, $125^{\circ} \mathrm{F}$. An increase in the rotor speed from 500 to $750 \mathrm{rpm}$ resulted in a marked change in the quality of product. At $500 \mathrm{rpm}$, a highly concentrated liquid was produced. At $750 \mathrm{rpm}$, the product started out as a highly concentrated liquid, but midway through the trial, a paste-like material was produced. Finally, toward the end of the experiment, a solid, 
chunky material was produced. These observations indicated that rotor speed was a significant parameter for supernate concentration.

Therefore, ten additional runs were added to the matrix. Eight of the trials were added in order to perform trials at all combinations of flow rate and feed tank temperature at $750 \mathrm{rpm}$. Two additional experiments were performed at $250 \mathrm{rpm}$ (to make a total of three) and $0.3 \mathrm{gal} / \mathrm{min}$. Three evaporator feed tank temperatures were investigated at these conditions-ambient, $125^{\circ} \mathrm{F}$, and $175^{\circ} \mathrm{F}$. These trials were performed to determine whether volume reduction was a linear function of rotor speed. It was assumed that whatever relationship was found at $0.3 \mathrm{gal} / \mathrm{min}$ would also occur at 0.1 and $0.5 \mathrm{gal} / \mathrm{min}$. Table 5 gives the trial conditions of the supernate studies.

In addition to this matrix, a series of optimization trials was performed. The purpose of this series of trials was to determine whether or not a paste-type substance that dried on cooling could be produced. A product with this consistency was believed to be best for storage at WIPP because it would contain no free-standing liquids and would minimize the void spaces and respirable fines. No analytical data are reported on the optimization experiments since a definitive set of conditions that would produce the paste could not be determined. Product quality was extremely sensitive to feed rate. A feed tank temperature of $125^{\circ} \mathrm{F}$ was used for all of the optimization experiments. This value was chosen because it was mid-range of the values tried in the experimental matrix. Several rotor speeds between 500 and $750 \mathrm{rpm}$ were tried.

Above a feed rate of $0.32 \mathrm{gal} / \mathrm{min}$, a completely liquid product was produced. Below a feed rate of $0.28 \mathrm{gal} / \mathrm{min}$, a dry, chunky product was produced. It appeared that if this $0.04-\mathrm{gal} / \mathrm{min}$ window were approached from the high end, a liquid would be produced until the lower value was approached, at which time a solid would be produced. Similarly, if the window was approached from the low end, a solid would be produced until the upper value was approached, at which time a liquid was produced. The paste-like material appeared only as a transient product as the quality of product changed from liquid to solid or vice versa.

A total of 25 studies was performed using the surrogate supernate. This combined with the water studies amounted to well over $100 \mathrm{~h}$ of operating experience for the evaporator. 
Table 5. Experimental matrix for supernate studies

\begin{tabular}{|c|c|c|c|}
\hline Run \# & $\begin{array}{l}\text { Flow rate } \\
(\mathrm{gal} / \mathrm{min})\end{array}$ & $\begin{array}{l}\text { Rotor speed } \\
\text { (RPM) }\end{array}$ & $\begin{array}{l}\text { Preheat tank temperature } \\
\qquad\left({ }^{\circ} \mathrm{F}\right)\end{array}$ \\
\hline 1 & 0.1 & 500 & Ambient \\
\hline 2 & 0.3 & 500 & Ambient \\
\hline 3 & 0.5 & 500 & Ambient \\
\hline 4 & 0.1 & 500 & 125 \\
\hline 5 & 0.3 & 500 & 125 \\
\hline 6 & 0.5 & 500 & 125 \\
\hline 7 & 0.1 & 500 & 175 \\
\hline 8 & 0.3 & 500 & 175 \\
\hline 9 & 0.5 & 500 & 175 \\
\hline 10 & 0.1 & 750 & Ambient \\
\hline 11 & 0.3 & 750 & Ambient \\
\hline 12 & 0.5 & 750 & Ambient \\
\hline 13 & 0.1 & 750 & 125 \\
\hline 14 & 0.3 & 750 & 125 \\
\hline 15 & 0.5 & 750 & 125 \\
\hline 16 & 0.1 & 750 & 175 \\
\hline 17 & 0.3 & 750 & 175 \\
\hline 18 & 0.5 & 750 & 175 \\
\hline 19 & 0.3 & 250 & Ambient \\
\hline 20 & 0.3 & 250 & 125 \\
\hline 21 & 0.3 & 250 & 175 \\
\hline
\end{tabular}

Table 6 gives a synopsis of the experimental results. . In Table 6, the feed temperature and feed tank temperature are different because some of the heat used to heat the evaporator was conducted back through the feed line. The feed line was also heat traced. Two of the planned experiments (runs 13 and 16) were not performed because a maximum amount of drying had been achieved at the same feed tank temperatures and flow rates but at a rotor speed of $500 \mathrm{rpm}$. Since the amount of drying 
Table 6. Results of supernate studies ${ }^{a}$

\begin{tabular}{|c|c|c|c|c|c|c|c|}
\hline $\begin{array}{r}\text { Flow rate } \\
\text { (gal/min) }\end{array}$ & $\begin{array}{l}\text { Rotor speed } \\
\text { (Ipm) }\end{array}$ & $\begin{array}{c}\text { Feed tank } \\
\text { temp. } \\
\left({ }^{\circ} \mathrm{F}\right)\end{array}$ & $\begin{array}{c}\text { Feed } \\
\text { temp. } \\
\left({ }^{\circ} \mathrm{F}\right)\end{array}$ & $\begin{array}{l}V_{r} \\
(\%)\end{array}$ & $\begin{array}{c}\mathrm{DF} \\
\left(\mathrm{C}_{\mathrm{a}} / \mathrm{C}_{\mathrm{ao}}\right. \\
\left.\times 10^{-4}\right)\end{array}$ & $\left(\begin{array}{c}\mathrm{U}_{0} \\
\frac{\mathrm{Btu}}{\mathrm{h}-\mathrm{ft}^{2}-{ }^{\circ} \mathrm{F}}\end{array}\right)$ & $\begin{array}{c}\text { Heat } \\
\text { Transfer } \\
\text { Eff. (\%) }\end{array}$ \\
\hline 0.1 & 500 & Ambient & 136 & $58^{*}$ & 3.61 & 39 & 63 \\
\hline 0.3 & 500 & Ambient & 136 & 34 & 1.51 & 60 & 71 \\
\hline 0.5 & 500 & Ambient & 132 & 19 & 1.81 & 68 & 86 \\
\hline 0.1 & 500 & 125 & 164 & $58^{*}$ & 1.68 & 45 & 71 \\
\hline 0.3 & 500 & 125 & 164 & 44 & 1.92 & 71 & 74 \\
\hline 0.5 & 500 & 125 & 162 & 50 & 1.59 & 93 & 96 \\
\hline 0.1 & 500 & 175 & 196 & $\mathrm{NT}^{*}$ & 1.68 & NT & NT \\
\hline 0.3 & 500 & 175 & 200 & 68 & 0.412 & 168 & 75 \\
\hline 0.5 & 500 & 175 & 200 & 56 & 1.33 & 185 & 95 \\
\hline 0.1 & 750 & Ambient & 136 & $\mathrm{NT}^{*}$ & 0.62 & 54 & 86 \\
\hline 0.3 & 750 & Ambient & 132 & 64 & 0.04 & 113 & 85 \\
\hline 0.5 & 750 & Ambient & 137 & 50 & 0.50 & 152 & NT \\
\hline 0.1 & 750 & 125 & - & - & - & - & - \\
\hline 0.3 & 750 & 125 & 162 & $66^{*}$ & 2.15 & 116 & 77 \\
\hline 0.5 & 750 & 125 & 161 & 57 & 1.55 & NT & NT \\
\hline 0.1 & 750 & 175 & - & - & - & - & - \\
\hline 0.3 & 750 & 175 & 199 & $53^{*}$ & 1.21 & 149 & 86 \\
\hline 0.5 & 750 & 175 & & 61 & 1.72 & 187 & 66 \\
\hline 0.3 & 250 & Ambient & 130 & 29 & 0.67 & 61 & 83 \\
\hline 0.3 & 250 & 125 & 169 & 49 & 0.41 & 104 & 79 \\
\hline 0.3 & 250 & 175 & 200 & 62 & 0.35 & 135 & 87 \\
\hline
\end{tabular}

an this table a dash (-) is used to indicate that a run was. not made. An asterisk $\left.{ }^{*}\right)$ indicates solid product. "NT" means that insufficient data were taken to perform the calculation 
increases with rotor speed and since the maximum amount of drying possibly had resulted from less severe conditions, it was assumed that these experiments would produce the same results as the corresponding 500-rpm runs.

\subsection{ANALYSIS}

A wide range of volume reductions was achieved. As expected, because of the void spaces, the maximum possible amount of drying did not give the largest volume reduction. There was also a large variation in the consistency of solid product. Figures 3 and 4 are photographs of the solid product from two separate trials. Figure 3 shows a product having a consistency comparable to that of talcum powder, while Fig. 4 shows a chunky solid. Run 8 produced a substance that was a combination concentrated liquid/paste/chunky solid. All runs at $0.1 \mathrm{gal} / \mathrm{min}$ and elevated feed tank temperatures produced a fine, dry powder. Under no set of conditions could a solid be produced at 0.5 $\mathrm{gal} / \mathrm{min}$. The optimization studies showed that the maximum flow rate at which a completely solid product could be produced was about $0.32 \mathrm{gal} / \mathrm{min}$. Stated another way, it can be said that this evaporator will dry $3.6 \mathrm{gal} /\left(\mathrm{h}-\mathrm{ft}^{2}\right)$. This value was about $68 \%$ of the design value of $5.3 \mathrm{gal} /\left(\mathrm{h}-\mathrm{ft}^{2}\right)$. The area term indicates the heat transfer surface area of the evaporator.

The design specifications for the evaporator call for a nominal 0.040-in. clearance between the wall of the evaporator and the blades. A preliminary inspection of the evaporator revealed that for this particular evaporator, the gaps averaged about 0.060 in. This could have caused the diminished rate of heat transfer. Postexperiment observations of the equipment also revealed that two of the blades were frozen at an angle of about $45^{\circ}$ from the radius. These two things may explain why the evaporator did not operate as efficiently as anticipated.

\subsubsection{Effect of Feed Rate and Feed Temperature}

Figure 5 is a graph of volume reduction vs flow rate for ambient feed temperature and 500-rpm rotor speed. Similarly shaped volume reduction vs flow rate plots may be produced for other sets of constant parameters. Figure 6 shows the relationship between 


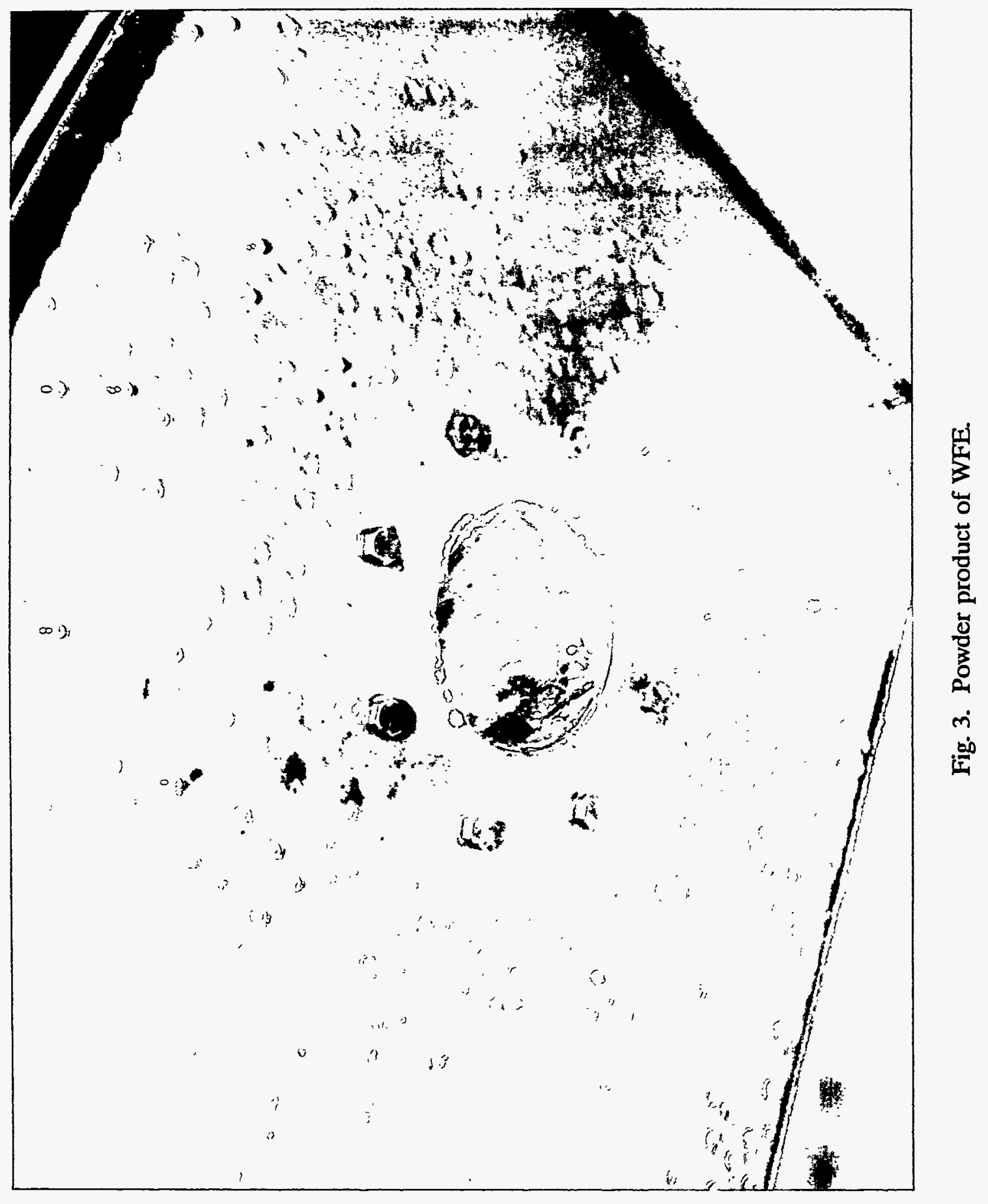




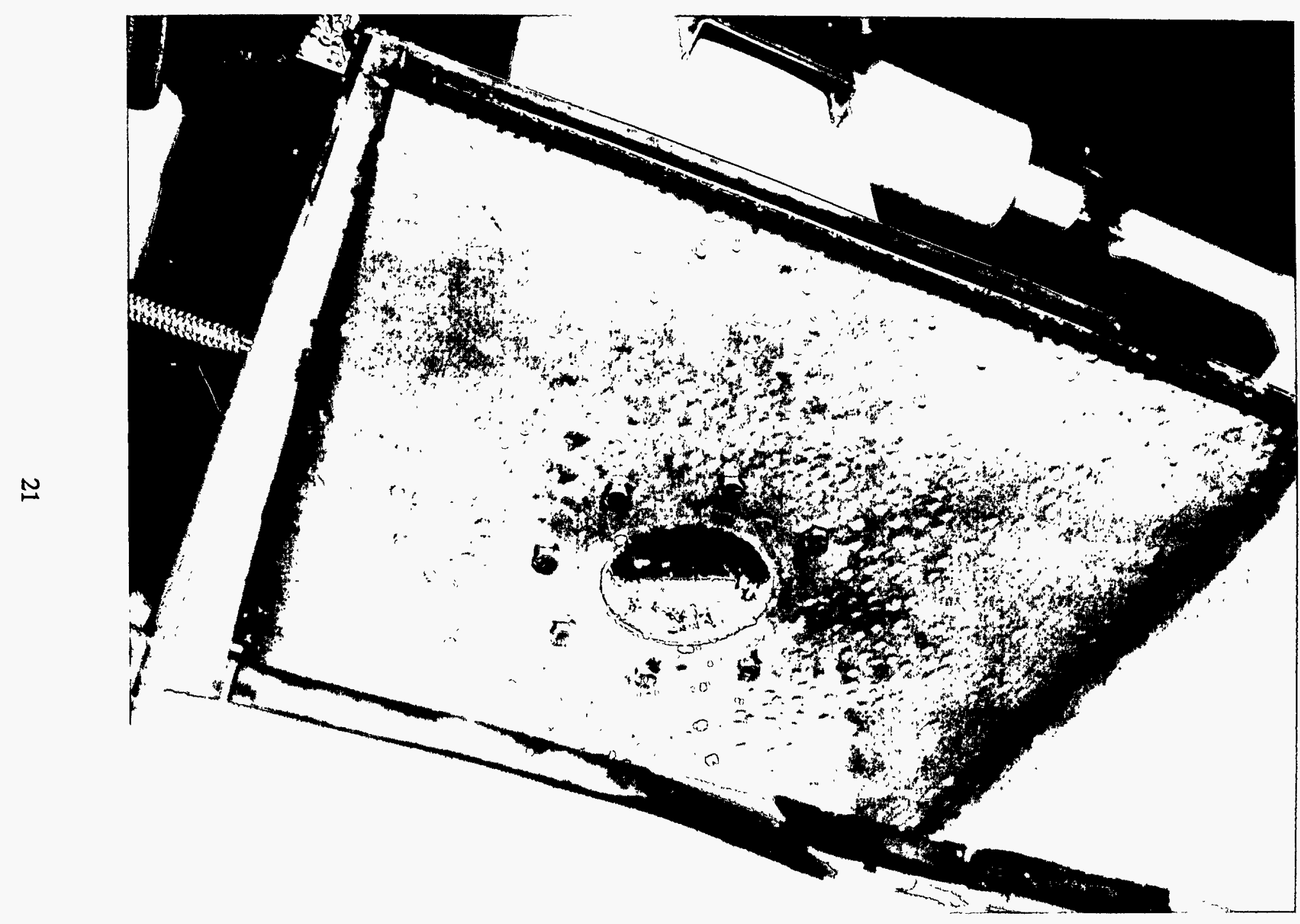

Fig. 4. Chunky product of WFE. 


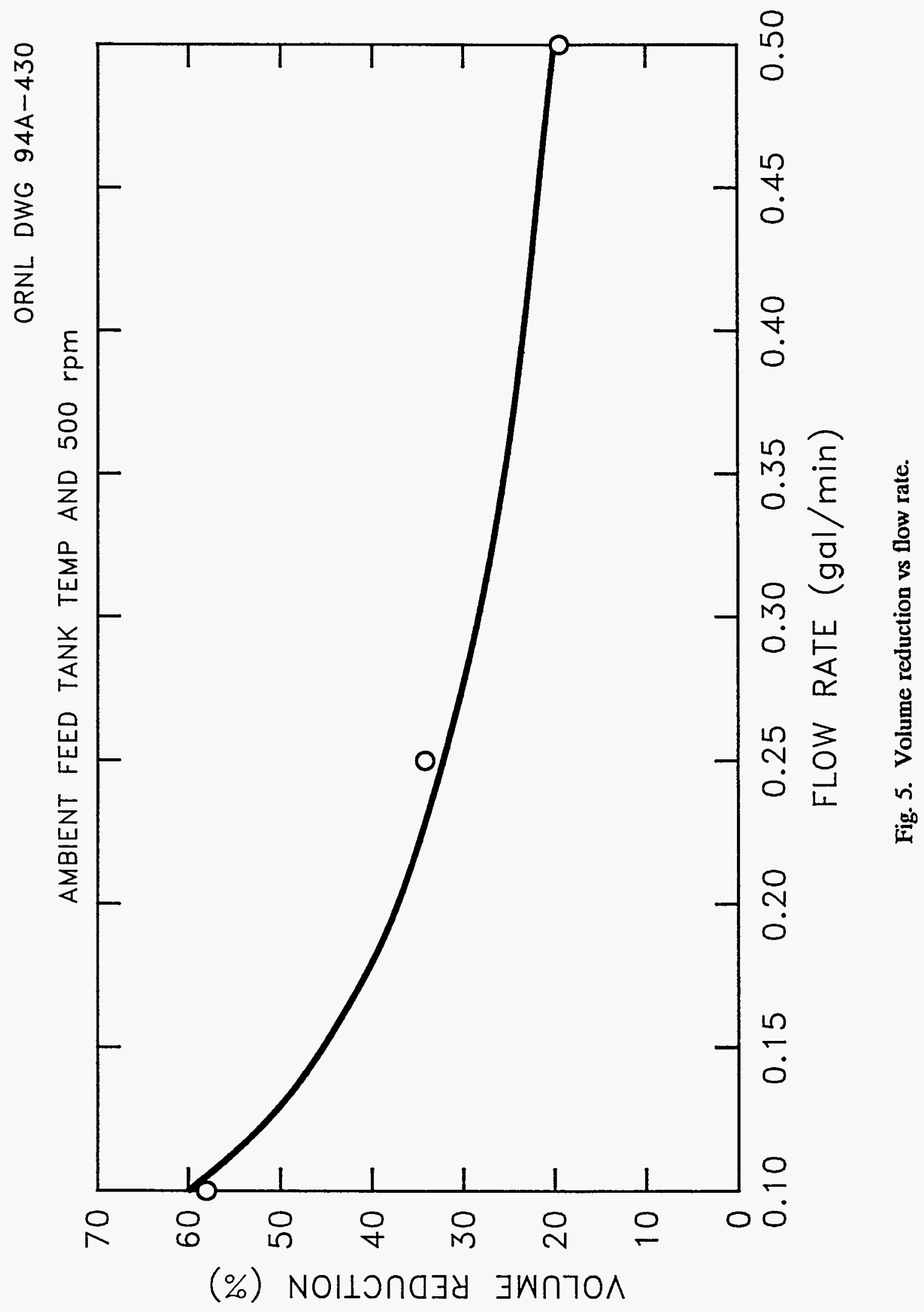




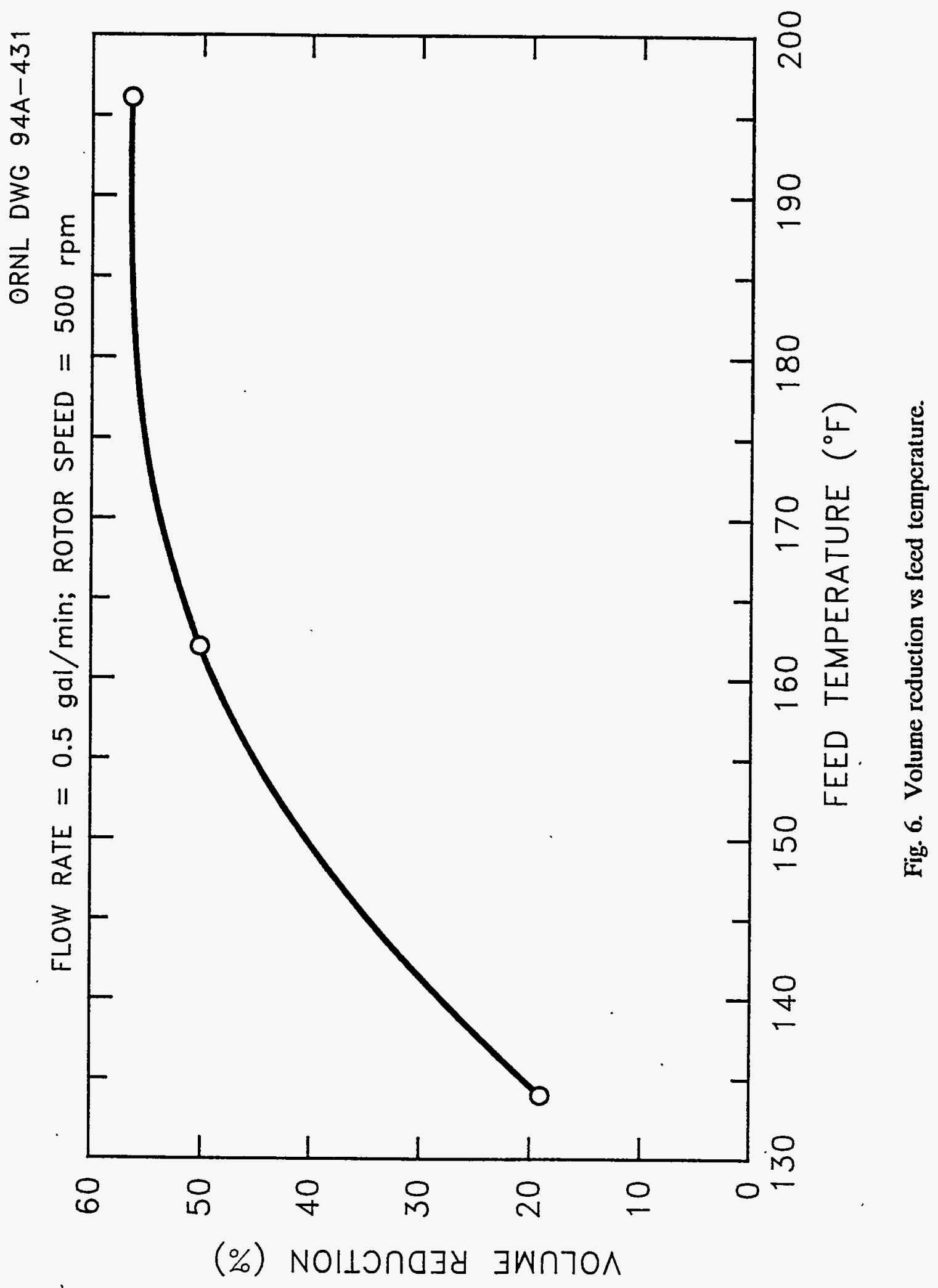


volume reduction and feed temperature. As would be expected, volume reduction is generally an inverse function of feed rate. The only time when this is not the case is when a porous powder is produced. Also, generally speaking, volume reduction is a proportional function of feed temperature. Once again, this assumes a nonporous product.

Feed rate and feed temperature appeared to be strongly coupled to one another as far as determination of volume reduction is concerned. In general, higher flow rates require higher feed temperatures to obtain the same consistency of product, and volume reduction. At $0.1 \mathrm{gal} / \mathrm{min}$ feed rate a solid product was produced no matter what the feed temperature. Therefore, it should be possible to design an evaporator for WHPP with a surface area large enough to accommodate the anticipated flow rate. Nominal increased space allocation would be required inside a radiologically controlled area for an evaporator with a much larger surface area. A preheat facility would certainly require significantly more space. If the space were available, two half-sized evaporators might be used. This would make processing more flexible and less susceptible to dead time (i.e., when no processing could be done).

One argument that might be made for having a preheat facility is that it may diminish the possibility of an explosion associated with the interaction of nitrates and organics. Some of the MVSTs have relatively high total organic content (TOC). In particular, W-26 has a TOC of 0.854 wt \%. Furthermore, these concentrations may vary significantly throughout the various tanks. ${ }^{22}$ These concentrations may be significant enough to cause explosions-particularly at the high heating rates associated with a WFE.

The Savannah River Plant treats nitrate-based waste that contains organics. As a safety precaution, they do not allow heating rates to exceed $0.6^{\circ} \mathrm{C} / \mathrm{min} .{ }^{23}$ If a WFE were used to heat MVST waste, the heating rate would need to be on the order of $600^{\circ} \mathrm{C} / \mathrm{min}$ based on a calculated residence time of $0.15 \mathrm{~min}$. These calculations were based on the assumption of a 0.040 -in. blade clearance, a $70^{\circ} \mathrm{F}$ feed temperature, a 1.0 -gal $/ \mathrm{min}$ flow rate, and an exit temperature of $240^{\circ} \mathrm{F}\left(115^{\circ} \mathrm{C}\right)$. With a preheat station, this rate could be substantially decreased. Differential thermal analyses (DTA) experiments to help determine whether there is a valid concern over the TOC in the MVST are planned.

At $0.3 \mathrm{gal} / \mathrm{min}$ a solid product could be obtained if the feed was preheated. The quality of product could be varied by changing the inlet temperature. A concentrated 
liquid was produced at a rotor speed of $750 \mathrm{rpm}$ and an ambient preheat tank temperature. At $125^{\circ} \mathrm{F}$ preheat tank temperature a chunky product could be obtained at a 750-rpm rotor speed. A dry powder was produced at $750 \mathrm{rpm}$ and a feed tank temperature of $175^{\circ} \mathrm{F}$.

At no time could a solid be produced at a flow rate of $0.5 \mathrm{gal} / \mathrm{min}$. As the feed tank temperature was increased, more free water was evaporated. The products varied from a concentrated liquid at 500-rpm rotor speed and ambient feed tank temperature to a saturated liquid containing a large quantity of suspended solids at $750 \mathrm{rpm}$ and $175^{\circ} \mathrm{F}$.

This strong dependency of product quality on feed rate and feed temperature was most likely due to the changes in turbulence caused by changes in flow rate, and changes in the amount of heat transfer surface area used for sensible heating caused by variation of the feed temperature. During a conversation with Bill Glover of LCI Corporation, a manufacturer of thin film evaporators, he stated that approximately twice as much heat transfer surface area was required to provide a quantity of sensible heat as would be required to supply the same quantity of latent heat. He also stated that the increased turbulence created by the rotor was due primarily to the size of the "bow" wave created by the blades in the liquid. This wave, which is similar in appearance to a "surfers" wave, increases in size with flow rate. Turbulence increases with wave size. ${ }^{24}$ The disadvantage of using a higher flow rate to generate higher turbulence is that so much latent heat may be necessary to evaporate the liquid out of the material that it would be impossible to solidify the material in spite of the increased heat transfer. This was . observed during these studies. Therefore, use of a lower flow rate (giving poorer heat transfer) and a higher feed temperatures (less sensible heating) is necessary to produce a dry product.

\subsubsection{Effect of Rotor Speed}

Figure 7 shows the effect of rotor speed on volume reduction. In all cases, higher rotor speed produced an increase in volume reduction. This is to be expected since the faster the blades spin, the higher the overall heat transfer coefficient. At a flow rate of 
ORNL DWG $94 \mathrm{~A}-432$

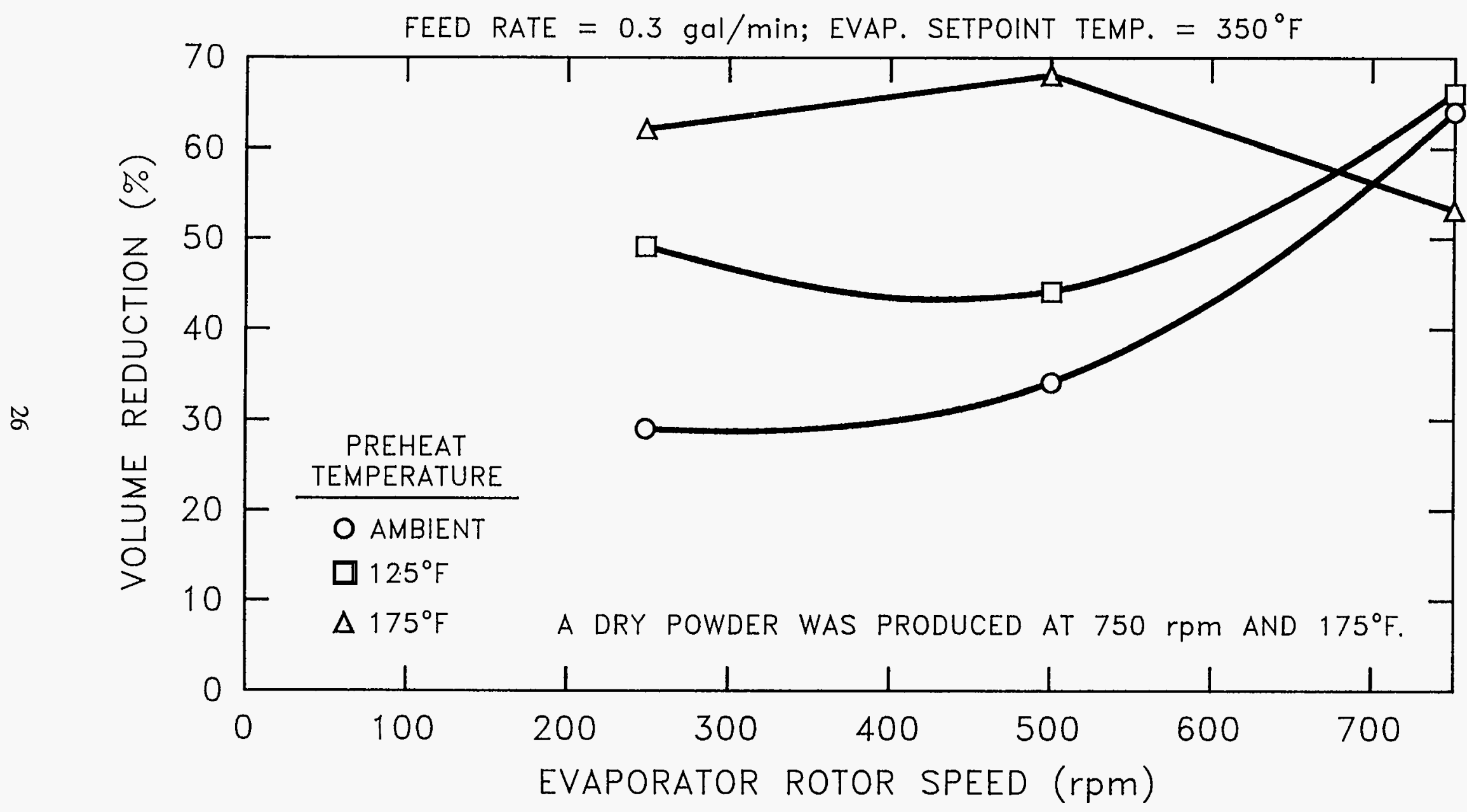

Fig. 7. Volume reduction vs rotor speed. 
$0.3 \mathrm{gal} / \mathrm{min}$, changes in rotor speed also made distinct changes in product quality. Products varied from a highly concentrated saturated liquid at a feed tank temperature of $175^{\circ} \mathrm{F}$ and $250 \mathrm{rpm}$ to a powder at the same feed tank temperature and $750 \mathrm{rpm}$. Again, this is most likely caused by the better heat transfer caused by greater turbulence at the higher rotor speed. Operation at a high rotor speed would appear to be the most cost-effective method for processing at WHPP since this would allow for processing at the highest possible flow rates-all other parameters being equal.

\subsubsection{Decontamination Factors}

Inductively coupled plasma (ICP) analyses indicated small but significant carryover of solids in the distillate. While most of the sodium concentrations for the distillate samples were reported as below the detection limits $(10 \mathrm{ppm})$ of the instrumentation, some of the concentrations were high. During run 15, the concentration of sodium in the distillate was reported as $761 \mathrm{ppm}$. This was the highest value reported. The conditions for this experiment were rotor speed, $750 \mathrm{rpm}$; feed tank temperature, ambient; and feed rate, $0.3 \mathrm{gal} / \mathrm{min}$. Since no unusual circumstances were noted during this experiment, no cause for this occurrence could be postulated.

Nitrate concentrations were analyzed by ion chromatography. The nitrate concentrations reported for the distillate agreed reasonably well stoichiometrically with the sodium and potassium concentrations calculated for the distillate using ICP. When the sodium concentration was reported as less than 10 , only a relative estimation could be made. However, the assumption that the sodium value was between $0-10 \mathrm{ppm}$ still gave stoichiometric agreement within $30 \%$. Since the nitrate concentration was a measurable value as opposed to a less-than value, it was believed that this number would be more accurate for the calculation of DFs. Therefore, the DFs were calculated as based on the nitrate concentrations. The analyses for the feed samples gave excellent agreement with the calculated values based on the makeup formula. The analyses on the product samples were scattered and considered questionable. Discrepancies of as much as $600 \%$ in either

direction were observed. DF values reported represent the system as opposed to the evaporator DFs since the quality of the analyses for the feed and condensate was superior to that of the product. Definitions of the two types of DFs may be found in the theory 
section of this report. These values averaged 1.64E4 for the system when based on nitrate analyses. A tabulation of these DFs may be found in Table 6. Some of the DFs were extremely low (on the order of $10^{2}-10^{3}$ ); however, they were generally in the range of $10^{4}$.

The majority of the values were found to be comparable to the DFs measured for cesium isotopes in one of the ORNL LLLW evaporators. ${ }^{25} \mathrm{It}$ is therefore believed that the DFs calculated based on nitrate analyses in the WFE would also be representative of the DFs for cesium. If an average DF of 20,000 is assumed for the radionuclides processed through WHPP and the concentrations reported in Sears ${ }^{26}$ accurately represent the concentrations in the MVST, then Table 7 should closely approximate the radioactivity in the distillate for WHPP. ${ }^{27}$ If the Process Waste Treatment Plant ( $\mathrm{rad}$ limit, $400 \mathrm{~Bq} / \mathrm{L}$ ) is to be the destination, further treatment of the distillate would be necessary. It would therefore be desirable to find some way of improving the DFs.

One way of improving the DFs in a WFE would be to lower the rotor speed. As noted earlier, lowering the rotor speed below $500 \mathrm{rpm}$ produced a significant decrease in volume reduction. In the previously cited conversation with Bill Glover of LCI Corp., he stated that for a 10 -in.-ID WFE, a minimum blade velocity of $31 \mathrm{ft} / \mathrm{sec}$ was necessary to create the desired turbulence in the heat transfer boundary layer. This corresponds to 500 rpm. At $500 \mathrm{rpm}$, the reported DFs are less than desired. Below $500 \mathrm{rpm}$, the volume reductions achieved were unsatisfactory. Therefore, reducing the rotor speed in this evaporator does not seem to be an acceptable means of controlling DFs.

Alval Corp. of Levan, UK, makes a specially designed WFE which is supposed to operate effectively at lower rotor speeds. This apparatus supposedly also has a better deentrainment section than other standard WFEs. No details on the design of this unit were given in the vendor literature. The literature did, however, claim lower entrainment of solids, which should translate to higher DFs. Further information on this equipment is currently being obtained.

\subsubsection{Heating Efficiency}

The only two parameters that showed a marked effect on the overall heat transfer coefficient were flow rate and rotor speed (see Table 6). The overall heat transfer 
Table 7. Estimated radiological contents of MVST condensate

\begin{tabular}{lrrrrrrrr}
\hline Emission/Isotope & $\begin{array}{c}\text { W-24 } \\
(\mathrm{Bq} / \mathrm{L})\end{array}$ & $\begin{array}{r}\text { W-25 } \\
(\mathrm{Bq} / \mathrm{L})\end{array}$ & $\begin{array}{c}\text { W-26 } \\
(\mathrm{Bq} / \mathrm{L})\end{array}$ & $\begin{array}{r}\text { W-27 } \\
(\mathrm{Bq} / \mathrm{L})\end{array}$ & $\begin{array}{r}\text { W-28 } \\
(\mathrm{Bq} / \mathrm{L})\end{array}$ & $\begin{array}{r}\text { W-29 } \\
(\mathrm{Bq} / \mathrm{L})\end{array}$ & $\begin{array}{c}\text { W-30 } \\
(\mathrm{Bq} / \mathrm{L})\end{array}$ & \multicolumn{1}{c}{$\begin{array}{c}\text { W-31 } \\
(\mathrm{Bq} / \mathrm{L})\end{array}$} \\
\hline Alpha & 2.16 & 86.2 & 444 & 7.76 & 19.0 & 4.31 & 4.31 & 0.431 \\
Beta & 99,100 & 169,000 & 948,000 & 142,000 & 422,000 & 88,800 & 82,800 & 154,000 \\
C-14 & 339 & 142 & 53.0 & 78.0 & 72.0 & 39.2 & 37.9 & 48.3 \\
Ce-144 & 319 & 560 & 991 & 323 & 776 & 575 & 53.1 & 336 \\
Co-60 & 142 & 810 & 5,260 & 133 & 3,760 & 269 & 211 & 139 \\
Cs-134 & 578 & 1,630 & 5,650 & 694 & 4,570 & 1,090 & 868 & 2,160 \\
Cs-137 & 95,300 & 141,000 & 892,000 & 93,100 & 244,000 & 94,800 & 81,000 & 98,700 \\
Eu-152 & 138 & 69.0 & 90.5 & 47.4 & 720 & 90.5 & 86.2 & 40.1 \\
Eu-154 & 25.9 & 51.7 & 103 & 28.4 & 318 & 61.6 & 51.7 & 28.9 \\
Eu-155 & 172 & 297 & 517 & 172 & 401 & 309 & 286 & 181 \\
H-3 & 133 & 149 & 266 & 90.1 & 51.3 & 86.6 & 87.1 & 67.2 \\
Nb-95 & 121 & 272 & 60.3 & 12.9 & 51.7 & 272 & 23.7 & 14.2 \\
Ru-106 & 474 & 819 & 1,210 & 474 & 1,300 & 876 & 819 & 474 \\
Sr-90 & 394 & 8,410 & 211 & 24,000 & 75,400 & 3,050 & 2,900 & 31,800 \\
Zr-95 & 216 & 51.7 & 1116 & 22.4 & 94.8 & 43.5 & 42.7 & 24.6 \\
\hline & & & & & & & &
\end{tabular}


coefficient varied from a low value of $39 \mathrm{Btu} /\left(\mathrm{h}-\mathrm{ft}^{2}-{ }^{\circ} \mathrm{F}\right)$ at a flow rate of $0.1 \mathrm{gal} / \mathrm{min}$ and a rotor speed of $500 \mathrm{rpm}$ to a high value of $186 \mathrm{Btu} /\left(\mathrm{h}-\mathrm{ft}^{2}-{ }^{\circ} \mathrm{F}\right)$ at a flow rate of $0.5 \mathrm{gal} / \mathrm{min}$ and a rotor speed of $750 \mathrm{rpm}$. These values are $10-80 \%$ lower than the $200-300 \mathrm{Btu} /(\mathrm{h}-$ $\mathrm{ft}^{2}-\mathrm{F}$ ) predicted using information provided by the vendor.

It is interesting to note that the lowest overall heat transfer coefficient was achieved at the conditions of the best volume reduction. Furthermore, some of the best overall heat transfer coefficients were achieved at the conditions of the worst volume reductions. Generally, when the largest volume reductions were achieved, the wall of the evaporator was lined with solids. Thus an additional resistance to heat transfer was added within the evaporator. This may have made the assumption that material was leaving the evaporator at the liquid boiling point a poor one. At low flow rates, the walls of the evaporator were probably not fully wetted because of to the high rate of evaporation and the extremely small amount of fluid being distributed over a relatively large area. The fact that not all of the heat transfer surface was being used would help explain why the overall heat transfer coefficient appeared lower at these conditions. Stated another way, the low flow rate may have decreased the effective area in the heat transfer equation. A preexperimental inspection report indicated that there was for the most part a higherthan-specified gap between the edge of the blades and the heat transfer surface. A nominal gap of 0.045 in. was specified in the design criterion. Measurements of the gaps of the bottom four blades showed gaps ranging up to 0.10 in., with the majority of the measurements in the $0.060-0.080$-in. range. ${ }^{28}$ These trends may indicate that the blade gap is too large to keep the heat transfer surface covered-particularly at lower flow rates where the blades would be less likely to contact the solution. Finally, when the unit was disassembled for the dimensional analysis, it was discovered that because of fatigue in the hinge pins, two of the blades were frozen at $\sim 45^{\circ}$ from the axial position. These blades probably had little effect on the enhancement of heat transfer. For these reasons, no effort was made to calculate $h_{i}$ during the supernate trials.

The fact that the highest overall heat transfer coefficients were calculated at the highest rotor speed was to be expected since turbulence in the boundary layer is known to promote heat transfer. The increase in overall heat transfer coefficient with flow rate was most likely due to more of the heat transfer surface being used. At a $0.5-\mathrm{gal} / \mathrm{min}$ flow rate, the product was a concentrated liquid. Therefore, all of the heat transfer surface was 
being used to either heat or evaporate the liquid. Furthermore, there was enough liquid present to allow the blades to fully wet the surface.

During the runs in which solid product was made, there was a significant amount of solid material caked on the heat transfer surface. The caked material may have served to bridge the gap between the blades and the side wall of the evaporator, thus making for more turbulent heat transfer. This cake may have also served to hold up the surrogate feed in the WFE for a long enough period of time to allow enough contact to evaporate the water in the surrogate supernate. Thermocouple readings in the evaporator steam jacket were noticeably higher $\left(\sim 340\right.$ vs $\left.\sim 320^{\circ} \mathrm{F}\right)$ when solid product was produced. The caked material must have acted as an insulator to the heat transfer surface, thus accounting for the higher skin temperature. This high skin temperature created a larger driving force for heat transfer on the process fluid side, which, in turn, produced better drying.

The screening experiments indicated very little improvement in evaporation for higher rotor speeds. During the supernate experiments, a very strong correlation between rotor speed and amount of evaporation was observed. This would seem to indicate that the blades were close enough to the surface to create some turbulence and to lower the effective viscosity for the Bingham Plastic-like product.

\subsubsection{Postinspection of WFE Components}

A corrosion inspection of the equipment was conducted following these supernate studies. To perform these corrosion inspections, it was necessary to remove the insulation around the evaporator. Since some problems had been experienced with the Netszch Model \#NE20A progressive cavity Nemo feed pump, the insulation was also removed from this unit, and the rotor and stator were replaced. The rotor and stator that had been in service during the studies were severely eroded. Deep grooves were observed in the 316 SS rotor where fluid flow would be expected (see Fig. 8). The soft rubber inside portion of the stator [ethylene propylene diene monomer (EPDM) construction] had deep gouges throughout. The stator had also been replaced after a similar problem had been encountered during the screening studies. This Netszch pump was used in these experiments for ease of flow control but would not be recommended for use in the 


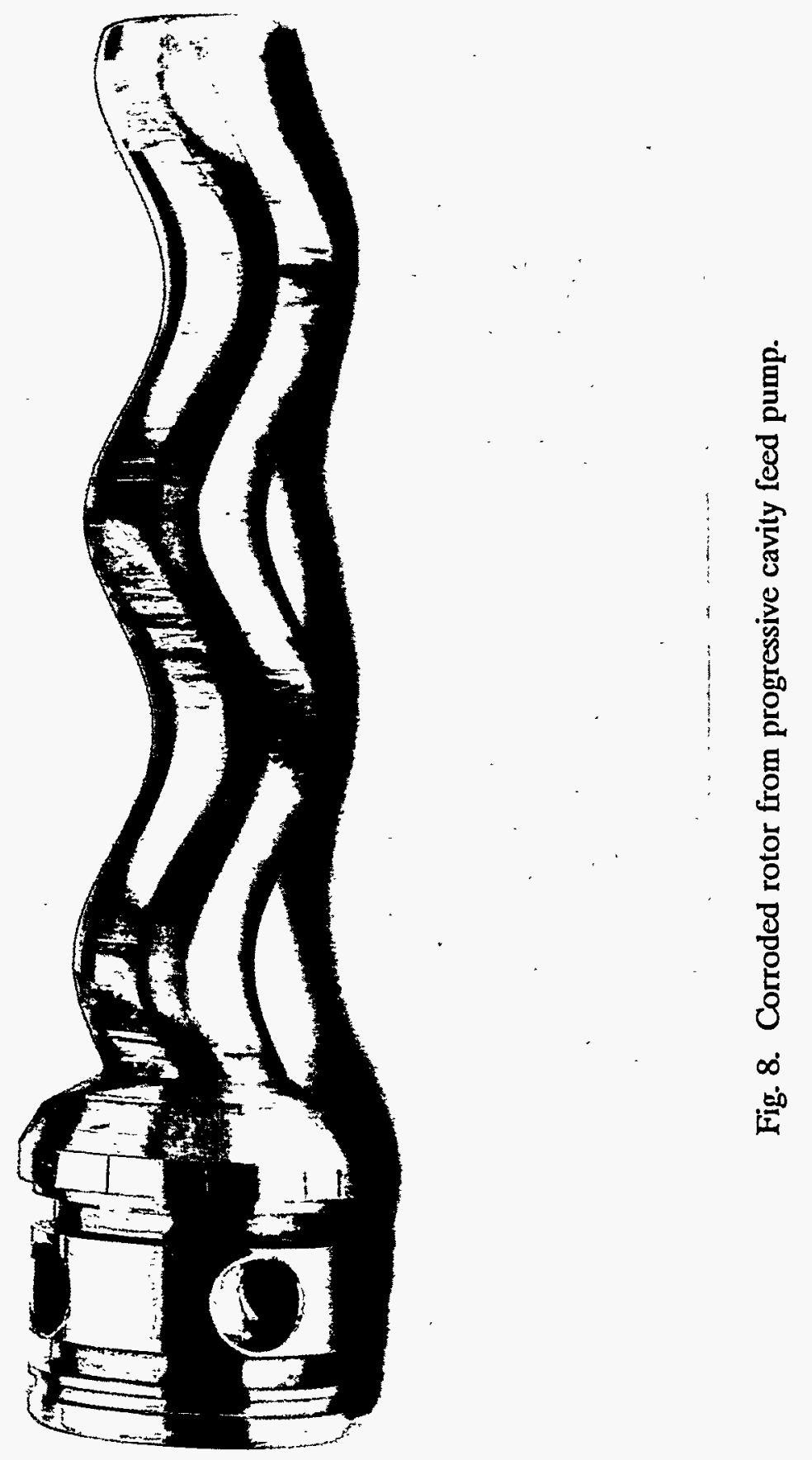


WHPP. A Moyno Pump Model \#213/SSB/AAA progressive cavity pump was installed after completion of the supernate studies; it is currently being evaluated.

A significant amount of rust-type corrosion products was observed on the heat transfer surface during the preliminary corrosion inspection of the WFE (see Fig. 9). The surface was scarred. This was to be expected because during several experiments, the rotor could be heard rubbing against the sides of the evaporator. In a conversation with Dane Wilson, a corrosion expert from ORNL's Metals and Ceramics Division, he stated that he believed that the rust-type corrosion was iron oxide. He is currently performing surface analysis to fully characterize this substance. It was also his belief that prevention of rubbing between the blades and heat transfer surface was imperative. ${ }^{29}$ Some of the rust-like corrosion was also visible on the blades. Several of the blades were severely eroded (see Fig. 10).

The rotor was constructed with four sections of blades (see Fig. 11). Each of these sections has two hinged blades attached to it. For purposes of the corrosion inspection, the blades were numbered sequentially from 1 through 8 , with blades 1 and 2 being located in the bottom quarter of the evaporator. During a visual inspection of the evaporator, one of the blades in the second section from the top (blade 6-the one photographed in Fig. 10) appeared to be rubbing one side of the heat transfer surface and not the other. No rubbing was visible in the top section.

Rubbing around the entire circumference of the heat transfer surface was observed in the shell where the bottom two blade sections rotated. The blades in the bottom three sections were all eroded to some extent. The blades in the second section from the top appeared to be the worst case. A close examination of blade 6 revealed that the bottom bushing holding the blade against the pin had slipped out of place. This had apparently allowed the bottom of this blade to rub against the side of the shell, since significant wear was observed on the lower half of this blade. Approximately 0.0625 in. of the bottom of this blade was eroded, while minimal damage was done to the top half. The pins on blades 4 and 5 were severely bent. These blades were "frozen" at $45^{\circ}$ angles axially. These blades most likely provided little assistance to heat transfer.

All of the pins and bushings were damaged enough to require replacement prior to resumption of operation. The pins were bent outward from the shaft in the direction of 


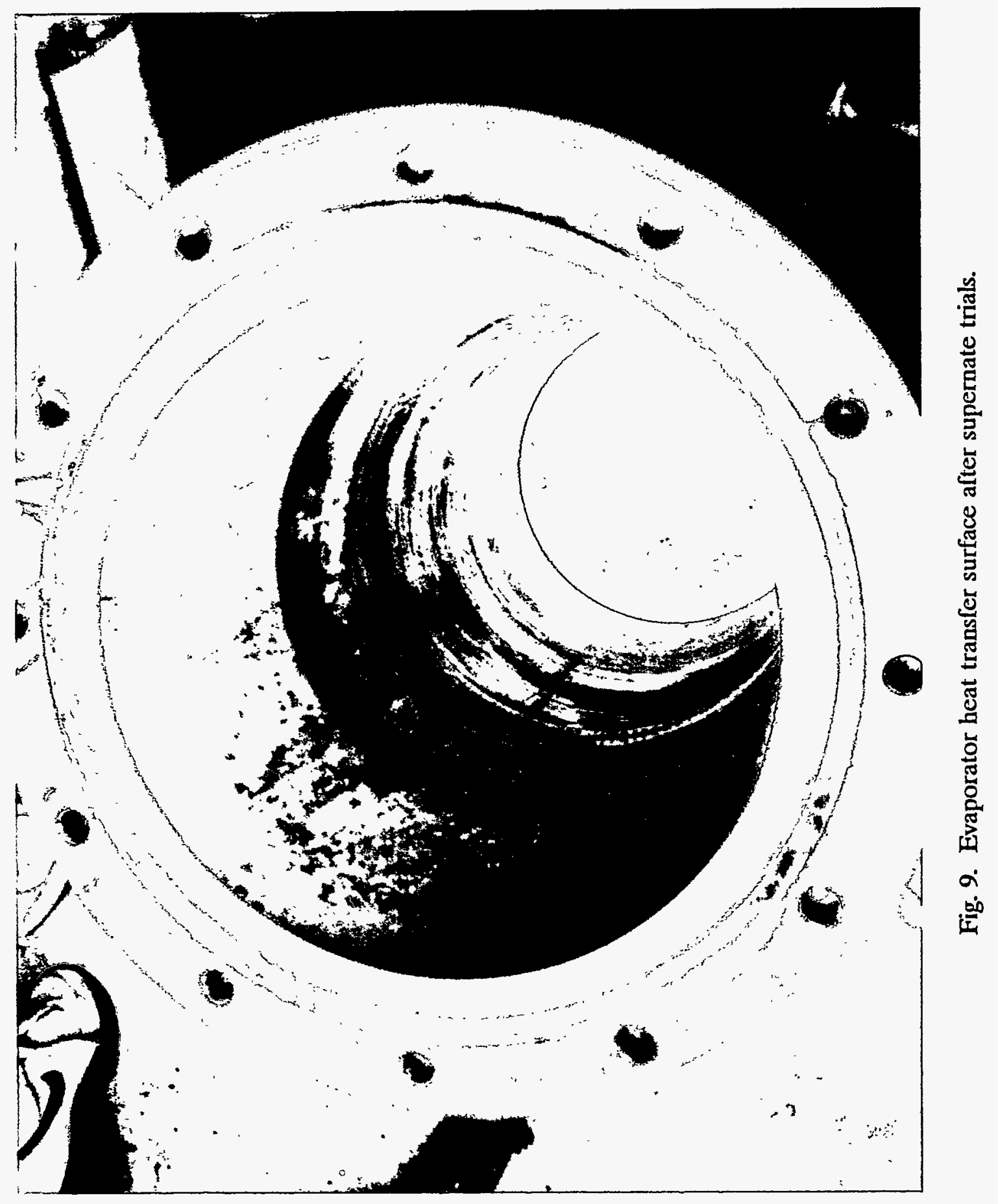




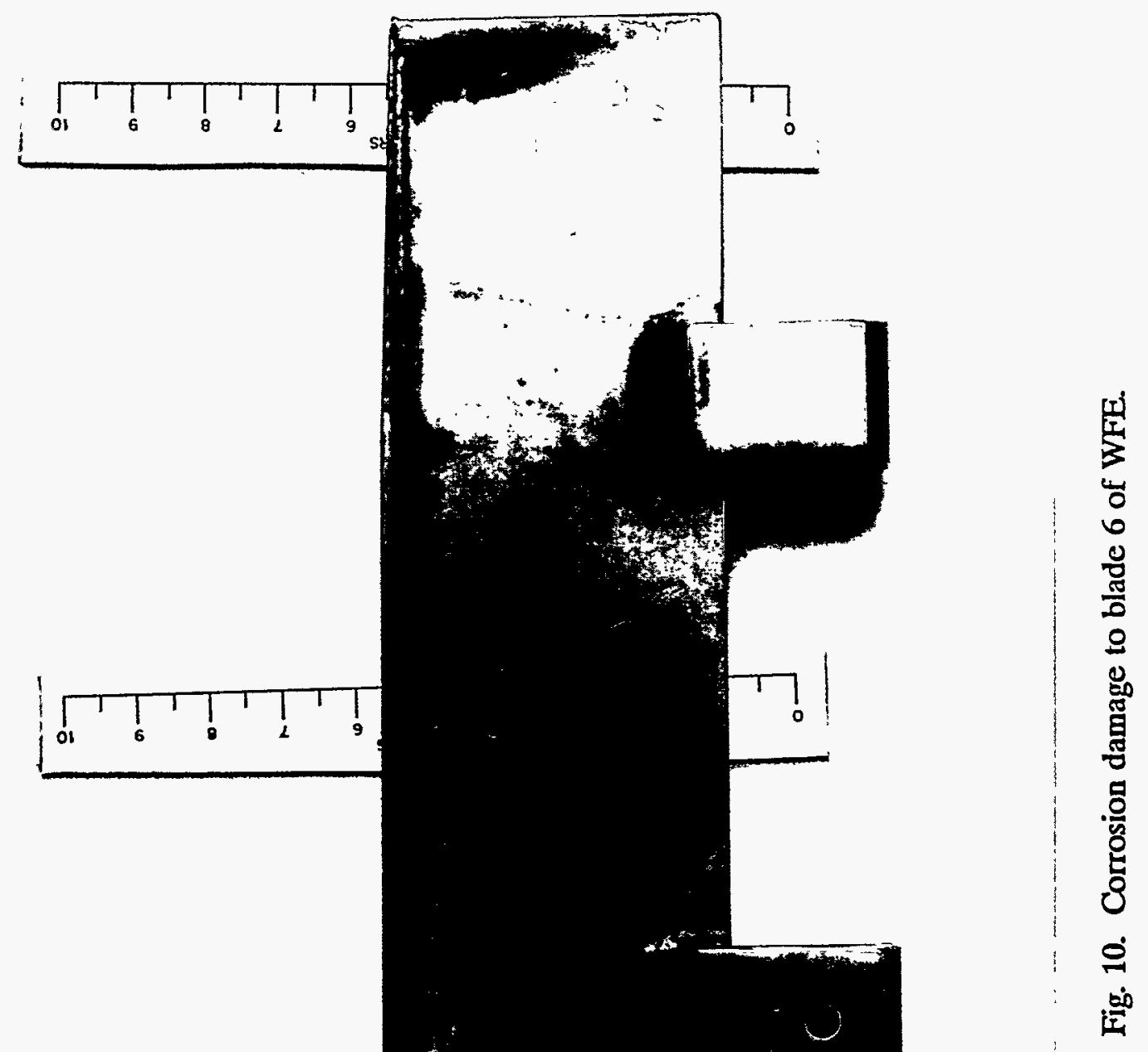




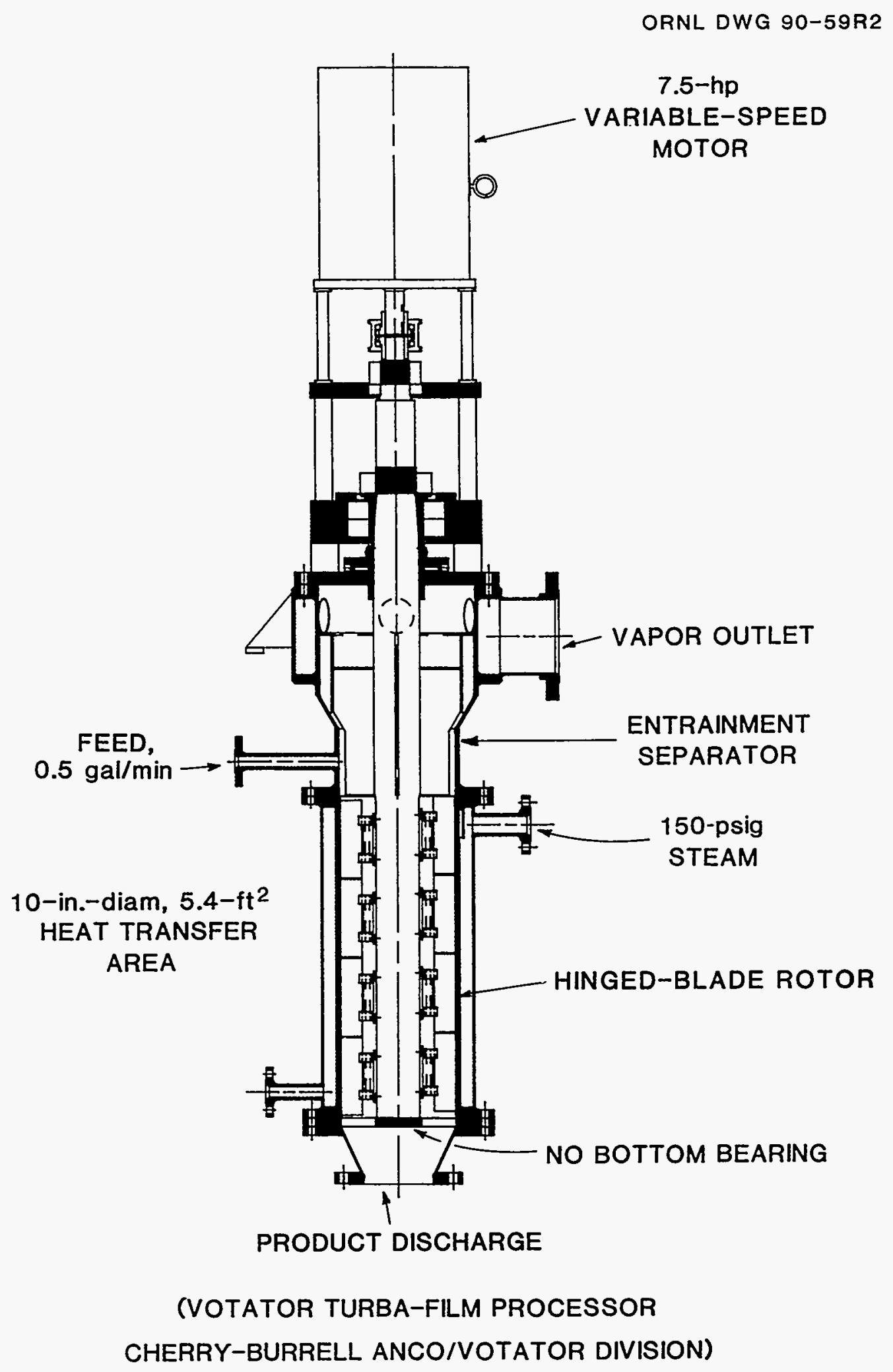

Fig. 11. WFE test unit. 
the heat transfer shell. The manufacturer's specifications called for the pins to be made of Stellite. Radiographs of the Stellite pins provided with the equipment revealed flaws in the metal. Time constraints during the WFE construction in 1990 did not allow procurement of new Stellite pins because of the lack of availability of the alloy. ${ }^{30}$ New pins were fabricated by the manufacturer out of an available alloy. Subsequent analyses by Metals and Ceramics $(M \& C)$ Division personnel revealed that this material was most likely 304 SS. This material is a relatively soft metal (Rockwell C 18 hardness), as measured by V. L. Fowler in about April 1990. Evidently, this relatively low-strength alloy was not able to tolerate the centrifugal and shearing stresses within the evaporator. Stellite is no longer manufactured because its mechanical properties are too difficult to control. It was therefore recommended by $\mathrm{M} \& \mathrm{C}$ that new pins be constructed of coldwork-hardened Ultimet (Rockwell C 47 hardness), an alloy similar to Stellite which is manufactured by Haynes, Int. These pins were fabricated and installed after the inspection. ${ }^{31}$

The displaced bushing on blade 6 would explain the damage done there, but it does not explain the rubbing on one side of the heat transfer surface and not the other. This may be indicative of either (1) a significant angle of runout, (2) the shell being out of round, (3) the bolts fastening the shell to the mounting bracket being improperly torqued, (4) the bolt circle being out of round, or (5) the damage to the pins causing an imbalance to the rotor. An extensive investigation was conducted during the dimensional inspection to determine the cause of this irregular rubbing. A check of the rotor shaft runout revealed only 0.008 in. runout at the bottom of the shell. This could not have caused the rubbing problem. The shell inside diameter was measured for roundness along the vertical. Dimensions measured here were well within the limits of statistical error for roundness. The largest difference in the roundness measurements for the shell was 0.011 in. as measured on the diameter at $90^{\circ}$ increments. ${ }^{32}$ It is not believed that this could have caused the observed effects. Since the shell bolts had all been torqued to $30 \mathrm{ft}-\mathrm{lb}$ during installation, it is not believed that explanation three is a valid one. While the bolt circle being out of round may possibly have caused this, it is believed that the amount of damage to the shell would have required this out-of-roundness to be visually noticeable. There was no way of determining whether or not the damaged blades caused centrifugal 
imbalance that created enough wobble in the rotor to allow the blades to rub against the wall, but this is the most likely explanation.

A dye penetrant test was performed on the shell during the dimensional inspection. Results of this test and the other tests performed during this postsupernate study inspection work may be found in the cited inspection report. ${ }^{32}$ The dye penetrant test indicated that despite the severe rubbing that had occurred, the integrity of the evaporator shell and heat transfer surface had not been jeopardized. No significant decrease in wall thickness was observed either. Additional items that may be found in the inspection report include blade and pin weights, blade dimensions, pin radiographs, torquing requirements, and new blade/heat transfer surface clearances. Of note is the fact that the gaps between the blades and heat transfer surface are, in general, 0.010-0.020 in. tighter with the new pins than with the originals. This most likely occurred because the new bushings that were installed in the hinges were drilled slightly off center, pushing some of the blades closer to the wall. This should enhance heat transfer in subsequent experiments.

A significant amount of distillate was sucked through the ventilation system despite the presence of demisters. This problem was more serious when the feed was preheated, indicating that at least some of the distillate was coming from the preheat tank. However, even when the feed was not being preheated, a more than acceptable amount of distillate was being sucked into the ventilation system. The demisters in the present system may be somewhat undersized, but it is doubtful that new, larger demisters would reduce the problem to an acceptable level. This could not be tolerated during operation of the WHPP. An unsuccessful effort was made to control this problem by manually adjusting ball valves in the various ventilation lines. Currently negative pressure is drawn on the evaporator via a 0.5 -in. line running from the condensing heat exchanger through an electronically controlled air- actuated valve. The condensate in the heat exchanger at the point where this line is attached may exist in two phases because of the partial vacuum. It may be that the vapor phase of the cooled condensate is being sucked through the ventilation system. During subsequent experiments, an effort will be made to establish the necessary negative pressure on the evaporator by exhausting through the distillate receiver tank. However, the problem could be easily overcome by the use of a cyclone separator upstream of the exhaust system. 
During the collection of many of the distillate samples, a mist was observed coming out of the sample line. Despite adjustments made to the regulated pressure downstream of the exhaust, this misting could not be completely eliminated. Regulated pressures from 0-1 in. of water were tried without success. Problems with the proportional integral derivative (PID) control loops in the control system made this pressure impossible to closely control. When the instrumentation is reworked for the slurry experiments, another effort will be made to control this misting by variation of the regulated off-gas pressure.

Performance of the instrumentation was disappointing. A personal computer was used along with the software package GENESIS to control the system. These devices were also used for data collection. In this configuration, the computer interacts directly with the field hardware-that is, pumps, valves, etc. Control is accomplished by computer execution of algorithms. within GENESIS. While this type of control is normally acceptable for laboratory applications, computer technology is not advanced enough to provide reliable control for industrial applications - particularly in industrial processes where severe failure consequences may occur. Normally, when used in industrial processes where safety and process control requirements are severe, the computer is used in conjunction with intelligent hardware. In this configuration, the intelligent hardware is the actual controlling device. The computer is merely an interface between the operator and intelligent hardware which allows for creation, downloading, and change of the control algorithms. The actual control is accomplished by downloading these algorithms to the intelligent hardware. The hardware executes the control algorithms. ${ }^{33}$ When the sludge studies are performed, the current system will be replaced by this type of system. It is likely that this sort of control will also be necessary should a production facility be built.

\section{CONCLUSIONS}

Preliminary studies to determine to what extent a surrogate MVST supernate can be concentrated have been completed. Results of these experiments indicate that a variety of products can be produced with the WFE. It was possible to vary consistency from a highly concentrated liquid to a completely dry powder. Volume reductions of from 19.8 to $68 \%$ were calculated. Decontamination factors in the range $10^{4}-10^{5}$ were achieved. Overall heat transfer coefficients ranged between 39 and $186 \mathrm{Btu} /\left(\mathrm{h}-\mathrm{ft}^{2}-{ }^{\circ} \mathrm{F}\right)$. 
These values are considered low for this type of equipment. Inside heat transfer coefficients were not calculated for this series of experiments.

While the equipment was found to be easy to operate and durable, several areas of concern were found. The 304 SS pins holding the blades onto the shaft were not strong enough to withstand the forces generated during operation. It is believed that the failure of these pins is the primary reason for the relatively poor heat transfer characteristics.

New pins made of an alloy known as Ultimet have been installed for subsequent experiments. 


\section{VARIABLE DICTIONARY}

\begin{tabular}{|c|c|c|}
\hline Variable & Description & Units \\
\hline$A$ & area & $\mathrm{ft}^{2}$ \\
\hline $\begin{array}{l}C \\
C p\end{array}$ & $\begin{array}{l}\text { concentration } \\
\text { heat capacity }\end{array}$ & $\begin{array}{l}\mathrm{g} / \mathrm{L} \\
\mathrm{Btu} /\left(\mathrm{lb} \cdot{ }^{\circ} \mathrm{F}\right)\end{array}$ \\
\hline $\mathrm{DF}$ & decontamination factor & Dimensionless \\
\hline$E$ & efficiency & Dimensionless \\
\hline$h_{f c}$ & heat of crystallization & Btu/lb \\
\hline$g$ & acceleration due to gravity & $\mathrm{ft} / \mathrm{s}^{2}$ \\
\hline$h_{f g}$ & latent heat of vaporization & $\mathrm{Btu} / \mathrm{lb}$ \\
\hline$h$ & enthalpy & Btu/lb \\
\hline$h_{i}$ & inside film heat transfer coefficient & $\mathrm{Btu} /\left(\mathrm{h} \cdot \mathrm{ft}^{2} \cdot{ }^{\circ} \mathrm{F}\right)$ \\
\hline$h_{0}$ & outside film heat transfer coefficient & $\mathrm{Btu} /\left(\mathrm{h} \cdot \mathrm{ft}^{2} \cdot{ }^{\circ} \mathrm{F}\right)$ \\
\hline$k$ & thermal conductivity & $\mathrm{Btu} /\left(\mathrm{ft} \cdot{ }^{\circ} \mathrm{F}\right)$ \\
\hline$L$ & length & $\mathrm{ft}$ (unless noted) \\
\hline$m$ & mass & $\mathrm{lb}$ \\
\hline$\underline{m}$ & mass flow rate & $\mathrm{lb} / \mathrm{h}$ \\
\hline$N$ & revolutions per minute & Dimensionless \\
\hline$Q$ & total heat & Btu \\
\hline$r$ & radius & in. \\
\hline$t$ & time & $\mathrm{h}$ \\
\hline$V_{r}$ & volume reduction & $\%$ \\
\hline $\begin{array}{l}T \\
U\end{array}$ & temperature & ${ }^{\circ} \mathrm{F}$ \\
\hline$U_{0}$ & overall heat transfer coefficient & $\mathrm{Btu} /\left(\mathrm{h} \cdot \mathrm{ft}^{\circ} \cdot{ }^{\circ} \mathrm{F}\right)$ \\
\hline \multicolumn{3}{|c|}{ Greek } \\
\hline $\begin{array}{l}\mu \\
\rho\end{array}$ & $\begin{array}{l}\text { viscosity } \\
\text { density }\end{array}$ & $\begin{array}{l}\mathrm{lb} /(\mathrm{ft}-\mathrm{h}) \\
\mathrm{lb} / \mathrm{ft} \mathrm{t}^{3}\end{array}$ \\
\hline$\dot{\eta}$ & kinematic viscosity & $\mathrm{ft}^{2} / \mathrm{s}$ \\
\hline \multicolumn{3}{|c|}{ Subscripts } \\
\hline $\begin{array}{l}a \\
d\end{array}$ & $\begin{array}{l}\text { species a } \\
\text { distillate }\end{array}$ & \\
\hline$p$ & product (except for heat capacity) & \\
\hline$\lambda$ & precipitated solids & \\
\hline$t$ & total & \\
\hline$f$ & \multirow{4}{*}{\multicolumn{2}{|c|}{$\begin{array}{l}\text { final except } h_{f} \text { and } h_{f} g \text { where it means saturated liquid } \\
\text { liquid } \\
\text { log mean } \\
\text { initial }\end{array}$}} \\
\hline$l$ & & \\
\hline LM & & \\
\hline$i$ & & \\
\hline
\end{tabular}




\section{REFERENCES}

1. S. M. Depaoli, ORNL's Engineering Development Section, personal communication, December 21, 1993.

2. S. M. Robinson, T. E. Kent, and S. M. DePaoli, Status of the ORNL Liquid Low Level Waste Management Upgrades, Draft, in preparation, June 1994.

3. E. L. Youngblood, ORNL Chemical Technology Division and former lead engineer on project, personal communication, March 14, 1994.

4. Preliminary Conceptual Design Report for the Waste Handling and Packaging Plant, No. $X O E-454$, Oak Ridge National Laboratory, Central Engineering Service Dept., Sect. 2.1.3.3.1, May 1989 .

5. Arne R. Gudheim and James Donovan, "Heat Transfer in Thin Centrifugal Processing Units," Chemical Engineering Progress 53 (10), 476 (October 1957).

6. L. L. Kilpatrick, Wiped Film Evaporator Process for Producing Defense Waste Salt Cake, DPST-82-398, Draft, Savannah River Laboratory, Aiken, S.C., April 1980.

7. J. F. Walker et al., "Concentration of Remote Handled Transuranic, Sodium Nitrate Based Sludge Using Agitated Thin Film Evaporators," Oak Ridge National Laboratory, presented at AIChE Summer National Meeting, August 18-21, 1991.

8. Concentration of Simulated Atomic Waste Solution, Process Development Report PD 11.88, prepared by Cherry Burrell Corp. for Martin Marietta Energy Systems, October 1988.

9. R. J. Vedder, Selection of an Agitated Thin Film Evaporator for Processing a Radioactive Waste at ORNL, ORNL/CF-89/289, Oak Ridge National Laboratory, October 1989.

10. Heat Transfer and Crystallization, Swenson Evaporator Co., Harvey, Ill., 1945.

11. E. L. Lustenader et al., "The Use of Thin Films for Increasing Evaporation and Condensation Rates in Process Equipment," Journal of Heat Transfer (November 1959).

12. K. Dieter, "Heat Transfer and Partial Distillation in Thin Film Evaporators," Chem. Eng. Technology 6 (30), 715-720 (1958).

13. J. T. Sommerfield, "Mathematical Modeling of Wiped Film Evaporators," DP-1405, E. I. Du Pont de Nemours and Company, Savannah River Plant, Aiken, S.C., May 1976.

14. A. H. P. Skelland, "Scale-up Relationships for Heat Transfer in Votators," British Chemical Engineering (June 1958).

15. V. L. Fowler, and J.J. Perona, Evaporation Studies on Oak Ridge National Laboratory Liqud Low Level Wastes, ORNL/TM-12243, Oak Ridge National Laboratory, 1993. 
16. I. Barin et al., Thermochemical Properties of Inorganic Substances, Springer-Verlag, Berlin, 1970.

17. J. H. Perry (editor-in-chief), Chemical Engineer's Handbook, 5th edition, McGraw-Hill, New York, 1973.

18. F. Franks (editor), Water: A Comprehensive Treatise, The Physics and Physical Chemistry of Water, Vol. I, Plenum Press, 1972.

19. M. B. Sears et al., Sampling and Analysis of Radioactive Liquid Wastes and Sludges in the Melton Valley Storage Tanks and Evaporator Facility Storage Tanks at ORNL, ORNL/TM-11652, Oak Ridge National Laboratory, September 1990, p. 41.

20. L. Dubin et al., "Deposit Control in High Silica Water," Materials Engineering Section, presented at Conference of National Association of Corrosion Engineers, 1985, pp. 27-33.

21. Mike Martin, Cherry Burrell Corp., personal communication, circa 1989.

22. W. D. Bond, ORNL chemist, personal communication, August 1993.

23. W. C. Perkins et al., The Safety of $\mathrm{UO}_{3}$ Production in the A-Line at the Savannah River Plant, E. I. Du Pont de Nemours and Co., Savannah River Laboratory, Aiken, S.C., March 1977, p. 36.

24. Bill Glover, LCI Corp., personal communication, May 5, 1994.

25. T. E. Kent, ORNL Engineering Development Section, personal communication, July 15, 1993.

26. M. B. Sears et al., Sampling and Analysis of Radioactive Liquid Wastes and Sludges in the Melton Valley Storage Tanks and Evaporator Storage Tanks at ORNL, ORNL/TM-11652, Oak Ridge National Laboratory, September 1990, Appendix C.

27. J.R. Parrot, Oak Ridge National Laboratory Liquid Waste Treatment Systems Waste Acceptance Criteria, \#WM-WMCO-201, Oak Ridge National Laboratory, Office of Waste Management and Remedial Actions Waste Management Programs, Waste Management Coordination Office, August 1990, p. 1.

28. Baseline Inspection Report of the WFE, ORNL Quality Division No. IR 13966, July 20, 1990.

29. Dane Wilson, ORNL Metals and Ceramics Division, personal communication, April 7 , 1994.

30. Lloyd Youngblood, ORNL Engineering Development Section, personal communications, August 1992.

31. Letter from H. E. McCoy to M. D. Boring, September 23, 1994. 
32. ORNL Inspection Plan and Dimensional Inspection Report \#IR 13966, Revised October 25, 1993.

33. M. T. Hurst, Instrumentation and Controls Division, ORNL, personal communication, March 1993. 


\section{INTERNAL DISTRIBUTION}

1. M. R. Ally

2. P. E. Arakawa

3. J. M. Begovich

4. J. T. Bell

5. J. B. Berry

6. W. D. Bond

7-27. M. D. Boring

28. R. M. Canon

29. E. D. Collins

30. D. A. Conatser

31. A. G. Croff

32. T. L. Donaldson

33-37. L. L. Farr

38-42. V. L. Fowler

43. W. Fulkerson

44. R. K Genung

45. T. M. Gilliam

46. R. W. Glass

47-51. J. D. Hewitt

52. T. D. Hylton

53. T. E. Kent
54. A. P. Malinauskas

55. C. P. Manrod

56. R. C. Mason

57. L. E. McNeese

58. Jim Moore

59. J. J. Perona

60. Eric Redmon

61. S. M. Robinson

62. C. D. Scott

63. Jim Snyder

64. Doug Turner

65. R. T. Vedder

66. J. F. Walker

67. T. L. White

68. E. L. Youngblood

69. Central Research Library

70. Document Reference Section

71-72. Laboratory Records

73. ORNL Patent Section

\section{EXTERNAL DISTRIBUTION}

74. S. L. Brown, PAI Corporation, 116 Milan Way, Oak Ridge, TN 37830

75. David B. Chamberlain, P.E., Separation Science and Technology Section, Argonne National Laboratory, 9700 South Cass Avenue, CMT/205, Argonne, IL 60439-4837

76. Office of Assistant Manager, Energy Research and Development, DOE-OR, P.O. Box 2001, Oak Ridge, TN 37831

77. Office of Scientific and Technical Information, P.O. Box 62, Oak Ridge, TN 37831 